Illinois State University

ISU ReD: Research and eData

Theses and Dissertations

$4-11-2014$

\title{
A Sequence Of French Vernacular Architectural Design And Construction Methods In Colonial North America, 1690-1850
}

Wade Terrell Tharp

Illinois State University, wttharp@gmail.com

Follow this and additional works at: https://ir.library.illinoisstate.edu/etd

Part of the Architecture Commons, and the History of Art, Architecture, and Archaeology Commons

\section{Recommended Citation}

Tharp, Wade Terrell, "A Sequence Of French Vernacular Architectural Design And Construction Methods In Colonial North America, 1690--1850" (2014). Theses and Dissertations. 229.

https://ir.library.illinoisstate.edu/etd/229

This Thesis is brought to you for free and open access by ISU ReD: Research and eData. It has been accepted for inclusion in Theses and Dissertations by an authorized administrator of ISU ReD: Research and eData. For more information, please contact ISUReD@ilstu.edu. 


\title{
A SEQUENCE OF FRENCH VERNACULAR ARCHITECTURAL DESIGN AND CONSTRUCTION METHODS IN COLONIAL \\ NORTH AMERICA, 1690-1850
}

\author{
Wade T. Tharp
}

81 Pages

December 2014

This study examines published and unpublished historical archaeological research, historical documents research, and datable extant buildings to develop a temporal and geographical sequence of French colonial architectural designs and construction methods, particularly the poteaux-en-terre (posts-in-ground) and poteauxsur-solle (posts-on-sill) elements in vernacular buildings, from the Western Great Lakes region to Louisiana, dating from 1690 to 1850 . Such a sequence is needed to provide a basis for scholarship, discovery, and hypotheses about prospective French colonial archaeological sites. The integration of architectural material culture data and the historical record could also further scholarship on subjects such as how the French in colonial North America used vernacular architecture to create and maintain cultural identity, and how this architecture carried with it indicators of wealth, status, and cultural interaction. 


\section{A SEQUENCE OF FRENCH VERNACULAR ARCHITECTURAL DESIGN}

\section{AND CONSTRUCTION METHODS IN COLONIAL}

NORTH AMERICA, 1690-1850

WADE T. THARP

A Thesis Submitted in Partial

Fulfillment of the Requirements

for the Degree of

MASTER OF ARTS

Department of Sociology and Anthropology

ILLINOIS STATE UNIVERSITY 
Copyright 2014 Wade T. Tharp 
A SEQUENCE OF FRENCH VERNACULAR ARCHITECTURAL DESIGN AND CONSTRUCTION METHODS IN COLONIAL

NORTH AMERICA, 1690-1850

WADE T. THARP

COMMITTEE MEMBERS:

Elizabeth M. Scott, Chair

Kathryn E. Sampeck 


\section{ACKNOWLEDGMENTS}

The writer wishes to thank Dr. Elizabeth M. Scott, whose steady guidance and persistent encouragement were nothing short of inspirational. The writer would also like to thank Dr. Kathryn E. Sampeck, whose feedback and suggestions about content and clarity were invaluable.

W.T.T. 


\section{CONTENTS}

ACKNOWLEDGMENTS

CONTENTS

TABLES

$\mathrm{V}$

FIGURES

\section{CHAPTER}

I. INTRODUCTION 1

Importance of Proposed Research 2

Theoretical Framework 3

$\begin{array}{ll}\text { Research Questions } & 7\end{array}$

Previous Architectural Research $\quad 8$

Review of Archaeological Literature $\quad 10$

$\begin{array}{ll}\text { Summary } & 14\end{array}$

II. FRENCH ARCHITECTURAL DESIGN AND CONSTRUCTION METHODS AND THE PROCESS OF COLONIZATION IN NORTH AMERICA

$\begin{array}{ll}\text { Introduction } & 16\end{array}$

$\begin{array}{ll}\text { Historical Background } & 17\end{array}$

$\begin{array}{ll}\text { Cahokia } & 18\end{array}$

$\begin{array}{ll}\text { Old Mobile } & 18\end{array}$

Kaskaskia 18

Fort Michilimackinac $\quad 19$

Fort de Chartres $\quad 19$

Ste. Genevieve $\quad 19$

Military Architecture 20

Civil, Commercial, and Residential Architecture 25

$\begin{array}{ll}\text { Summary } & 29\end{array}$ 
Descriptions of the Buildings Used in This Study

Structures in Natchitoches Parish, Louisiana $\quad 32$

Structures in New Orleans, Louisiana 33

Structures in Old Mobile (1MB94), Mobile County, Alabama 33

Structures in Cahokia, Illinois $\quad 36$

Structures in Prairie du Pont, Illinois $\quad 38$

Structures in Ste. Genevieve, Missouri $\quad 39$

Structures at Fort Michilimackinac, Michigan $\quad 40$

Analytical Methods $\quad 41$

Construction Dates for the Poteaux-en-Terre Buildings 43

Construction Dates for the Poteaux-sur-Solle Buildings 44

Summary 44

IV. DATA ANALYSIS AND INTERPRETATION 45

Data Analysis: Chronology of Construction Techniques 45

Mean Construction Date for Poteaux-en-Terre Structures 45

Median Construction Date for Poteaux-en-Terre Structures 47

Mode Construction Date for Poteaux-en-Terre Structures 47

Range of Construction Dates for Poteaux-en-Terre Structures 47

Mean Construction Date for Poteaux-sur-Solle Structures 47

Median Construction Date for Poteaux-sur-Solle Structures 48

Mode Construction Date for Poteaux-sur-Solle Structures 49

Range of Construction Dates for Poteaux-sur-Solle Structures 49

Data Analysis: Geographical Setting 49

Geographical Settings of Poteaux-en-Terre Structures 49

Geographical Settings of Poteaux-sur-Solle Structures $\quad 50$

Data Analysis: Chronology of Settlement Location 50

Interpretation: Chronology of Construction Techniques 54

Interpretation: Geographical Setting $\quad 56$

Interpretation: Chronology of Settlement Locations $\quad 59$

Summary 61

V. CONCLUSIONS AND RECOMMENDATIONS 63

$\begin{array}{ll}\text { Conclusions } & 65\end{array}$

$\begin{array}{ll}\text { Recommendations } & 70\end{array}$ 
REFERENCES 


\section{TABLES}

Table

Page

1. Poteaux-en-Terre Structures Studied, Ordered by Geographical Setting (column) and by Date of Construction (row)

2. Poteaux-en-Terre Structures Studied, Ordered by Geographical Setting (column) and by Date of Construction (row)

3. Mean and Median Construction Dates for Structures Studied in Old Mobile (1MB94), Mobile County, Alabama, Ordered by Geographical Setting (column)

4. Mean and Median Construction Dates for Structures Studied in Fort Michilimackinac, Michigan, Ordered by Geographical Setting (column)

5. Mean and Median Construction Dates for Structures Studied in Cahokia, Illinois, Ordered by Geographical Setting (column)

6. Mean and Median Construction Dates for Structures Studied in Natchitoches Parish, Louisiana, Ordered by Geographical Setting (column)

7. Mean and Median Construction Dates for Structures Studied in Ste. Genevieve, Missouri, Ordered by Geographical Setting (column)

8. Mean and Median Construction Dates for Structures Studied in New Orleans, Louisiana, Ordered by Geographical Setting (column)

9. Mean and Median Construction Dates for Structures Studied in Prairie du Pont, Illinois, Ordered by Geographical Setting (column)

10. Statistics Derived from Construction Dates 


\section{FIGURES}

Figure

Page

1. Geographical Settings of the Poteaux-en-terre and Poteaux-sur-solle Structures Studied 


\section{CHAPTER I}

\section{INTRODUCTION}

This study examines published and unpublished historical archaeological research, historical documents research, and datable extant buildings to develop a temporal and geographical sequence of French colonial architectural designs and construction methods, particularly the poteaux-en-terre (posts-in-ground) and poteauxsur-solle (posts-on-sill) elements in vernacular buildings, from the Western Great Lakes region to Louisiana, dating from 1690 to 1850 . Such a sequence is needed to provide a basis for scholarship, discovery, and hypotheses about prospective French colonial archaeological sites. The integration of architectural material culture data and the historical record could also further scholarship on subjects such as how the French in colonial North America used vernacular architecture to create and maintain cultural identity, and how this architecture carried with it indicators of wealth, status, and cultural interaction.

Whether European colonists during the seventeenth through the nineteenth centuries came to the New World for commercial opportunities or religious and social freedom, they carried to North America European cultural traits and conceptions that ultimately would help to shape the colonial experience in the New World. French colonists used traditional vernacular architectural designs and construction methods in North America as the basis of the colonization process. Architectural design was used in part to maintain control over indigenous North American populations, as well as to 
transport French cultural traditions to the colonies (Edwards 2006; Maygarden 2006). Additionally, architecture was used to structure social interaction between owner and slave, as well as between colonists and indigenous peoples (Herman 1999). French colonists altered traditional French construction methods, however, in order to adapt successfully to new physical and climatic environments, using locally obtainable materials rather than traditional materials that may have been too costly or difficult to acquire. Adaptations and adoptions notwithstanding, elements of French vernacular architectural designs and construction methods persisted; the persistence of these elements suggests that despite being thousands of miles from France-across a great ocean, and often well into the interior of North America - a considerable degree of "cultural memory" likewise persisted. While admittedly intangible, such "cultural memory" perhaps could indicate why aspects of certain designs and methods persisted after they had been supplanted by more practical (i.e., more economical or sturdy) designs and methods.

\section{Importance of Proposed Research}

While a number of archaeological investigations of French colonial sites in North America have taken place, along with a good deal of historical scholarship, a temporal and geographical sequence of French vernacular architectural styles and construction methods has yet to be compiled. Such a sequence will establish what types of architectural designs and construction methods were being used by the French in vernacular buildings, and will provide a basis for hypotheses about prospective archaeological sites. I hope that this thesis will fill this gap in the knowledge base by providing such a sequence. 
Such a sequence could provide data for interpretations of how French settlement patterns affected incorporation of vernacular building methods; how trade networks influenced what was built; how population pressures affected decisions about—and access to-labor and material resources; how decisions were made about where to settle; how European colonialist cultures functioned; how colonizers established and perpetuated cultural identity in new lands; how culture is maintained in colonial settings; and how creolization and ethnogenesis take place. Such research also could yield information useful to explaining how French colonists in North America interacted with France, and how they saw their place in the supply chain of information and materials from Europe. It could also lead to interpretations of the degree to which such intangibles as memory and nostalgia might have played roles in the practical lives of French colonists in the New World.

\section{Theoretical Framework}

My thesis will investigate how French vernacular architectural design and building methods in colonial North America can be interpreted to indicate European colonialism, wealth and status, the processes of colonization, and the persistence of cultural memory.

Dawdy (2000) argues that concepts of vernacular creolization derived from folk usage or from anthropological linguistics invite confusion between, "a Louisiana folk definition with an Anglo-American racial anxiety" (Dawdy 2000:108); and that such concepts effectively collapse the inherent nuances required for discernment, thus leading to potentially offensive or embarrassing classifications of race and ethnicity (Dawdy 2000:107-108). Dawdy notes that the forms of creolization, as seen archaeologically in 
New Orleans, were transplantation, ethnic assimilation, and hybridization (Dawdy 2000:119). In terms of material culture, transplantation is indicated as a trait of the first generation of immigrants; these settlers attempted to recreate the Old World via replications of familiar architecture, food preferences, and household organization. In the assemblage studied, this was suggested by the apparently heavy reliance upon French goods, and the relative absence of local materials (Dawdy 2000:119). Ethnic assimilation is associated with second generation individuals (that is, "native Creoles") who integrated New World products into daily life, and possessed an openness to using materials, designs and ideas that would have seemed native and foreign to their historical culture. In the assemblage studied, this was suggested by the presence of a significant amount of Native American and British pottery, as well as the adoption of French Caribbean architectural elements by Spanish colonials, as well as an apparent preference for local exotic food items (Dawdy 2000:119). Hybridization is associated with successive generations; Dawdy argues that hybridization "is made possible when the dominant ethnic culture loses some of its political and economic control and an impasse with competing groups encourages negotiation" (Dawdy 2000:119). This negotiation makes for a freer exchange of ideas and materials, and encourages quick acceleration of cultural change; a byproduct of hybridization can be that symbolic and political powers of material objects associated with previous, entrenched generations are purposefully devalued, and that ethnic distinctions are changed into more acceptable forms (Dawdy 2000:120). In the assemblage studied, this was suggested by a widow's refashioning of an old Creole house in the American fashion, and the lavish, status-conscious expenditures on such luxuries as the previous generation would have considered vulgar. 
In examining colonial economics and society of the Spanish Philippines, Skowronek (1998) interprets the use, by Spanish public institutions and private individuals, of traditional forms of architecture as being indicative of European colonialism and the processes of colonization (Skowronek 1998:52-56). Arguing that New World-focused archaeology of the postcontact era has demonstrated that a clear break appears in the archaeological sequence of pre-Columbian cultural traditions where Europeans settled; Skowronek suggests that these changes are evidenced both in architectural styles and city plans (Skowronek 1998:46-47). This study will investigate how French vernacular architectural design and building methods in colonial North America may be interpreted to indicate European colonialism and the processes of colonization.

In examining the maintenance of self-image by early Acadian elites in Maine, New Brunswick, and Nova Scotia; Faulkner (1992) interprets the presence, in the archaeological record and in historical literature, of items of material culture that seem incongruous with the hardships of the frontier as indicative of wealth and status (Faulkner 1992:98). Arguing that, though the elite members of societies at the outposts of Acadia were accustomed to lives at the end of infrequent, chronically unreliable lines of supply — and thus were accustomed to eking out every last bit of utility from durable goods-Faulkner suggests that they nonetheless used elements of material culture to perpetuate the symbols and rituals of French gentility and self-recognition, and to reinforce authority relationships (Faulkner 1992:97). This study will investigate how French vernacular architectural design and building methods in colonial North America may be interpreted to indicate wealth and status.

In examining the definition, the maintenance, and the ultimate loss of ethnicity by later French settlers in the Colony of New Bordeaux, in South Carolina, Steen (2002) 
interprets the settlers' yielding of their traditional names, types of livelihoods, language, and religion to those of their new home as a loss of ethnicity (Steen 2002:159). Steen notes that, over the course of two or three generations, during which colonial culture was changing rapidly and French settlers had the freedom either to maintain or to discard their cultural folkways, many chose to join the American Revolutionary cause, and subsequently chose to adopt the prevalent Anglo-European Georgian society folkways of their adopted land (Steen 2002:159). This study will investigate how French vernacular architectural design and building methods in colonial North America may be interpreted to indicate the persistence of cultural memory.

In discussing Italian Neolithic society, Robb (2007) states, "It is difficult to reconstitute a world of social reproduction based on the accumulation of small meanings, inherently intangible and elusive" (Robb 2007:220). While a culture's practices and nonmaterial aesthetics weave together to form what is commonly referred to as "cultural fabric," a culture's practices and material aesthetics also play roles in defining place and space. In providing comments on this study, Kathryn E. Sampeck (2014, pers. comm.) suggested the phrase "cultural masonry" to describe these practices and material aesthetics. French colonist's use, in North America, of familiar construction methods and building materials is an example of the use of a "cultural masonry" both to exhibit and to maintain cultural memory.

Colonization also presented opportunities either to maintain cultural traditions or to separate from them. For example, while many French colonists may have fondly recalled their homeland, French Protestants who were part of the outmigration spurred by religious persecution in the wake of the revocation of an edict allowing practice of 
Protestantism may have been likely to resist the persistence of cultural traditions directly related to their lives in France (Steen 2002).

I hope to provide a better understanding of how colonizers established and perpetuated cultural identity in new lands, and begin not only to describe ethnogenesis more thoroughly (i.e., to mark its paths, and to note its effects), but also to interpret ethnogenesis more thoroughly (e.g., to explain why—and at what points—it occurs, and to define its arc). French settlers in North America, whether engaging in fur trade practices, missionary work, military expeditions, or agriculture, created networks that ultimately resulted in the creation and maintenance of communities linked by kin networks and relationships (Mann 2008:324).

\section{Research Questions}

In order to establish a both a temporal and geographical sequence, this research will address how information from archaeological reports and extant dated buildings can be used to answer the following questions. 1) Can measurable temporal and geographical sequences be derived in vernacular architecture, from present historical archaeological data and extant dated buildings? 2) Did French colonists either replace poteaux-en-terre (posts-in-ground) with poteaux-sur-solle (posts-on-sill), or vice versa, or did they build in both styles contemporaneously; and if so, can measurable temporal and geographical sequences be derived to demonstrate such patterns? 3) How might such sequences, if found, be used to tie research of French vernacular architectural design and construction methods in North America into the larger body of scholarship in French colonialism? 4) What would retention of traditional French architectural designs and construction methods indicate? 5) What would be indicated by the adaptation of architectural designs 
and methods of indigenous peoples or slaves in French Colonial architecture? An answer to these questions could illustrate the processes that drove cultural change, creolization, and ethnogenisis; and how those processes resulted in the melding - to various degrees and effects — of such apparently diverse cultures as those of the Europeans, those of the Africans, and those of the Native Americans.

\section{Previous Architectural Research}

Although much research exists on French architectural traditions in North America, most of that scholarship has been done by architectural historians, who mostly deal with extant buildings. Architectural Historian Charles E. Peterson, for example, sought to describe the evolution of French vernacular architecture within the Middle Mississippi River Valley from the 1760s to the 1840s, relying upon historical documents and extant structures (Edwards 2006; Peterson 1938). Edward's research seeks to establish and explain how practical factors (e.g., knowledge, experience, ability to adapt existing designs and materials to new uses, and ability to adopt interactively new designs or materials from other cultures) might account for variations in architectural traditions among French colonial settlements in all of North America. Using historical data and onsite examinations of surviving structures, Edwards argues that the French vernacular architecture of the colonial period (the 1670 s to the 1840 s) is "something more than French architecture transported and environmentally adapted," and considers peasant builders' abilities to incorporate architectural elements of distant communities (e.g., from Africa and the Caribbean), non-vernacular sources (e.g., the military), and non-traditional materials, to demonstrate the emergence of architecture that was no longer Gallic, but rather Creole (Edwards 2006). Maygarden's research (2006) similarly interprets French 
architectural traditions among Louisiana Acadians between the 1720s and the 1810s via historical documents, extant structures, and limited archaeological evidence, arguing that that group's adherence to such traditions do not necessarily tie them so much to Creole planter elites as to French peasants.

In my opinion, both Edwards' and Maygarden's arguments are excellent, but leave untouched a few key topics about culture. For example, while Edwards' argument includes a great deal of information about architectural styles, it includes little discussion about the cultural interactions that produced them. While Maygarden's argument that Louisiana Acadians were more likely to take cues_-at least with regard to architecturefrom Creole petits habitants (rather than from the raised homes of the planter elites) explains the cultural milieu, it nonetheless stops short of incorporating discussions of status.

The major debates in the field of architectural history concern how architectural elements changed through time and space, and how these changes show the creolization processes, as well as the adaptation of colonizers to new physical environments and climates. One question, for example, is how were French Colonial architectural designs and construction methods in vernacular buildings in North America influenced by traditional designs and methods, from both Europe and the New World, as well as by designs and methods of indigenous populations, slaves, and settlers from other European countries? How were decisions to use these designs and methods influenced by economic, status, labor, and climate factors? 


\section{Review of Archaeological Literature}

The archaeological literature review included research into how historical archaeologists have looked at architecture and creolization, cultural identity, and ethnogenesis; as well as how historical archaeologists have looked at French colonization.

South (1979) notes the importance of considering associations between artifacts, architecture, features, strata, and spatial patterns (South 1979:221). South, grouping archaeologically-revealed data - that is, architectural ruins and architectural group artifacts_-argued that such data should reveal architectural features and functionally related architectural features (e.g., a series of postholes forming a structural outline), and reflect the subsystem that South classified as structural technology (South 1979:229).

Leone (1988), discussing the relationship between Georgian order and merchant capitalism in Annapolis, Maryland, argued that formal gardens - including related structures and landscape features_-associated with homes of successful local merchants were demonstrations of the builders' understanding of both natural and social order (Leone 1988:255). However, Leone's work on associated built environments largely focuses upon how housing firmly grounded in rules made for "orderly living" (Leone 1988:257).

Groover (1994), in an investigation of folkways, notes that Deagan's archaeological investigations of the de la Cruz/Gallardos site indicated that, "material culture associated with socially visible male activities, such as architecture and weaponry, was derived from Hispanic culture, whereas low-visibility female activities, such as food preparation, were heavily influenced by Native American culture (Groover 
1994:44)." Additionally, Groover suggests that some investigations of multicultural households indicate that socially visible material culture (e.g., architecture, imported tablewares, and apparel artifacts) demonstrates conformity with the standards and traditions of the principal colonizers, and is relatively resistant to change; whereas lowvisibility material culture (e.g., related to food consumption in informal settings, and clothing manufacture) often demonstrates a synthesis of cultural traditions (Groover 1994:55). Furthermore, Groover argues that, while archaeologically-derived socially visible material culture embodied a European ideal that planters' families wished to transplant and perpetuate along the interior frontier; relatively low-visibility archaeologically-derived material culture indicated departures from those ideals, underscoring the realities of frontier life, the nature of which often involved interactions between, and contributions from, diverse ethnic groups (Groover 1994:55-56).

Faulkner (1992) discusses the probate inventory of the personal property of a veteran French naval officer, Isaac de Razilly, who co-founded the Company of New France (Faulkner 1992:82). Fifty-eight percent of the items listed in the de Razilly probate inventory are identified by Faulkner as wardrobe items (clothing items and grooming items). Half of the clothing items are described in the inventory by decoration; many are appropriate in their degree of elegance and ornamentation to de Razilly's position of Lieutenant General of New France. In examining the maintenance of selfimage by these early Acadian elites in Maine, New Brunswick, and Nova Scotia; Faulkner interprets the presence, in the archaeological record and in historical literature, of items of material culture that seem incongruous with the hardships of the frontier as indicative of wealth and status (Faulkner 1992:98). Faulker argues that, though the elite 
members of societies at the outposts of Acadia were accustomed to lives at the end of infrequent, chronically unreliable lines of supply — and thus were accustomed to eking out every last bit of utility from durable goods - they nonetheless used elements of material culture to perpetuate the symbols and rituals of French gentility and selfrecognition, and to reinforce authority relationships (Faulkner 1992:97).

Birk (1991), in a look at French fur trade era in the Great Lakes area, addresses the seeming dichotomy between the visions of the trade as, on one hand, driven by the industriousness of adventurous, independent voyageurs, and on the other hand, driven by explorers and companies eager to exploit the rich natural resources of the New World (Birk 1991:238). Birk includes documentary evidence from the period, archaeological data from Little Elk Fort, pollen evidence from prehistoric times, early (1700) climatic data, and a geological description of the area. Birk contends that, because of its situation in time and space, the Little Falls site would be an uniquely ideal subject for further excavation, and could ultimately produce data useful in interpreting the lifeways of the voyageurs, "that illiterate class of French Canadian laborers so often ignored in contemporary written records" (Birk 1991:265).

While desire for the extension and expansion of power can be seen as the driving force behind a great deal of exploration and colonialism as practiced by political entities over the past 400 years, in many cases migration and subsequent population expansion were driven by population pressures and religious persecution. Steen (2002) describes the French presence in the South Carolina colony as having been the direct result of French Protestant outmigration. This outmigration was spurred by religious persecution in the wake of the revocation of an edict allowing practice of Protestantism (Steen 
2002:145-146). Steen suggests that because this migration was due to the religious persecution, these French migrants would have been unlikely to look too fondly upon their French origins. The integration of these Huguenots into otherwise overwhelmingly Scots-Irish settlements of Presbyterians are seen in the documentary and archaeological record as being manifested as cultural and stylistic breaks of the New World French Protestants with their traditional lifeways (Steen 2002:154). In examining lives of later French settlers in the Colony of New Bordeaux, in South Carolina, Steen interprets the settlers' yielding of their traditional names, types of livelihoods, language, and religion to those of their new home as a loss of ethnicity (Steen 2002:159). Steen argues that, over the course of two or three generations, during which colonial culture was changing rapidly and French settlers had the freedom either to maintain or to discard their cultural folkways, many chose to join the American Revolutionary cause, and subsequently chose to adopt the prevalent Anglo-European Georgian society folkways of their adopted land.

Nassaney et al. (2007) write about the Fort St. Joseph site in southwestern Michigan, an important French trading post from 1691 to 1761, located near an important portage (Nassaney et al. 2007:3). In contrast to archaeological artifacts recovered in settlements of dispossessed migrants (such as are found in Steen), those excavated (and surface collected by antiquarians) at Fort St. Joseph portray French colonists eager to maintain their heritage through both architecture and material culture. The fort was also used as a mission and a trading post (Nassaney et al. 2007:5). The authors' interpretation of the archaeological data is that although the French at Fort St. Joseph used many local materials in construction, the prevalence of such items as glass beads suggests that 
considerable effort was made to recreate familiar surroundings and decoration (Nassaney et al. 2007:14).

\section{Summary}

My thesis will investigate how French vernacular architectural design and building methods in colonial North America can be interpreted to indicate European colonialism, wealth and status, the processes of colonization, and the persistence of cultural memory.

While research by architectural historians on French architectural traditions is valuable, it has its limits. Archaeology can provide additional architectural evidence, as well as a time depth, that extant structures alone cannot. For example, while the inventory of extant buildings is skewed toward the presence of poteaux-sur-solle buildings, archaeologically recovered examples provide a greater range of building types (i.e., they include a greater presence of poteaux-en-terre buildings). At this writing, however, historical archaeology of North American French sites has not included a comparison of construction methods across time and space. Historical archaeologists, for their part, have focused generally on discussions of other, non-architectural material culture (e.g., ceramics, glass, etc.) rather than on analysis and discussion of architectural artifacts. Additionally, any anthropological discussion of the subject must also address such subjects as wealth, status, and cultural interaction.

During the course of this study, I intend to analyze data about architectural design and construction methods gathered from architectural material culture and historical documentation and to tie these analyses into discussions of wealth, status, and interaction between cultures (e.g., French, Africans, Native Americans), and generations. In this 
way, I hope to integrate architectural material culture into the historical record of the French in North America. 


\section{CHAPTER II}

\section{FRENCH ARCHITECTURAL DESIGN AND CONSTRUCTION METHODS AND THE PROCESS OF COLONIZATION IN NORTH AMERICA \\ Introduction}

This chapter will examine French architectural design and construction methods used in military, civil, commercial, and residential contexts; the processes of colonization in North America; and how French colonists coming to the New World brought with them cultural memories and conceptions which, when realized through architectural designs and building methods, helped them to create buildings and spaces with familiar cultural elements in a new place.

Colonial enterprises in the New World left marks, both in the ground and on the landscape, that remain even today. Whether colonists from France, Spain, the Netherlands, Britain, or other lands in Europe and Asia came for commercial opportunities, religious and social freedom, or other reasons, they all carried with them to North America cultural memories and conceptions; these memories and conceptions would ultimately help to shape the colonial experience in the New World.

The French used colonial architectural designs and construction methods in North America as part of the colonization process. French colonists used architectural designs (e.g., fortifications, settlements, etc.) to establish and maintain control over indigenous populations (Gérin-Lajoie 1976; Halchin 1985; Hall 1991; Heldman and Minnerly 1977; Keene 1991; Saucier and Seineke 1969; Walthall 1991). French colonists used also 
architectural designs (e.g., hipped roofs, galleries, etc.) to transport French cultural traditions and recreate them in the colonies, and to maintain a sense of "Frenchness" through time (Birk 1991; Faulkner 1992; Gérin-Lajoie 1976; Gitlin 1992; Gums 1998; Halchin 1985; Hall 1991; Heldman and Minnerly 1977; Katz 2004; Keene 1991; Saucier and Seineke 1969; Seale et al. 2002; Usner 1987; Walthall 1991; Waselkov 1997).

In addition to using architectural designs from the Old World, French colonists altered traditional French construction methods in order to adapt them to new physical environments, using locally obtainable materials (e.g., local woods, etc.) in preference to materials that would have been either more expensive or more difficult to obtain (e.g., stone, imported woods, etc.) (Gums 1998; Gums et al. 1991; Halchin 1985; Hall 1991; Heldman and Minnerly 1977; Katz 2004; Keene 1991; Saucier and Seineke 1969; Seale et al. 2002; Steen 2002; Usner 1987; Walthall 1991; Waselkov 1997). French colonists also altered traditional French construction methods (e.g., poteaux-en-terre to poteauxsur-sole, etc.) in order to adapt them to new cultural environments, which brought the French into close contact with cultures very different from those to which they were accustomed, in Europe (Gums 1998; Gums et al. 1991; Halchin 1985; Heldman and Minnerly 1977; Saucier and Seineke 1969; Seale et al. 2002; Usner 1987; Walthall 1991; Waselkov 1997).

\section{Historical Background}

The discussion of French colonial architectural design and construction methods as part of the North American colonization process benefits from an understanding of the French New World experience in the areas of study. 


\section{Cahokia}

Cahokia is located in what was known, during the seventeenth and eighteenth centuries, as the Illinois Country—so named for the Illini or Illiniwek Indian groups (Gums 1988:12). Although European contact was made with the Native American groups by French as early as 1672-1673 (i.e., Jesuit Father Jacques Marquette and Louis Jolliet) and 1679-1683 (i.e., Robert Cavelier LaSalle and Henri de Tonti), the first permanent Euro-American settlement on the Mississippi River that was known as Cahokia was established in 1699 at a village of the Tamaroa and Cahokia Indians (Gums 1988:13).

\section{Old Mobile}

Old Mobile — named for the Mobile Indians, whose small settlements were in the area-was established in 1702 by Pierre Le Moyne d'Iberville to serve as the newlyfounded colony of Louisana's military, political, and economic center (Waselkov 1997:3). Old Mobile was the heart of French Louisiana until the site was abandoned in favor of present-day Mobile's location at the head of Mobile Bay (Waselkov 1997:3). The site of the old settlement only received archaeological attention in 1970, after having been subjected to disturbances related to development by heavy industry in the 1950s and 1960s (Waselkov 1997:3).

Kaskaskia

Kaskaskia was founded on the east bank of the Mississippi River in 1703 by missionaries, coureurs de bois, and Kaskaskia Indians eager to avoid the hostile advances of the local Sioux Indians (Ekberg 1996:7). At first populated by farmers, fur traders, 
clerics, and Indians, there was no French political or military presence in the locality until the construction of Fort de Chartres (Ekberg 1996:7).

\section{Fort Michilimakinac}

Initially built by the French along the straits connecting Lake Michigan and Lake Huron sometime before or during 1715, Fort Michilimackinac provided military support to the area and to the fur trade (Heldman and Grange 1981). The fort was relinquished to the British in 1761; from 1781-1783, the British relocated some of the fort's structures, and rebuilt others from limestone, on Mackinac Island.

\section{Fort de Chartres}

Fort de Chartres — named in honor of Luc, duc de Chartres - was first built, during 1719-1721, as a wooden palisaded structure (Ekberg 1996:7). It was constantly being repaired and rebuilt until the 1750s, at which time the French government build a stone fort-intended to play a key role in French presence on the North American continent — at the site (Ekberg 1996:7).

Ste. Genevieve

Ste. Genevieve of the Illinois Country (as it was officially known) the first permanent French settlement west of the Mississippi River, initially was established sometime in the 1750s (Ekberg 1996:12). Ste. Genevieve was an offshoot of the French communities on the east bank of the Mississippi; French colonial authorities had been issuing land grants in the Grand Champ (i.e., the Big Field) since the 1740s, and habitants who owned and worked the land moved from the east bank, in order to be closer to their work (Ekberg 1996:11). However, severe flooding during the 1780s brought about an exodus to the north; individuals and families moved en masse from 
what became known as Old Ste. Genevieve to new sites at New Ste. Genevieve and Mont Généreux (later New Bourbon).

\section{Military Architecture}

Archaeological artifacts, material culture, and historical documentation associated with French colonial military sites in North America indicate that French colonists in North America used traditional French architectural designs to establish and maintain control over indigenous populations, to transport French cultural traditions and recreate them in the colonies, and to maintain a sense of "Frenchness" through time. Additionally, French colonists altered traditional French construction methods in order to adapt them to new physical and cultural environments.

French colonists used traditional French architectural designs when planning and building forts such as Fort Michilimackinac, Fort de Chartres, Fort Massac, and Fort St. Joseph, which were intended to support efforts to establish and maintain control over indigenous populations; this control was crucial to the protection of trade and supply routes (Gérin-Lajoie 1976; Halchin 1985; Hall 1991; Heldman and Minnerly 1977; Keene 1991; Nassaney 2008; Saucier and Seineke 1969; Walthall 1991).

The four so-called Intercolonial Wars were fought in North America between the French, their colonies, and their Indian allies, and Britain, its colonies, and its allies. The first was the King William's War, which began in 1689 and ended in 1697; the second was Queen Anne's War, which began in 1701 and ended in 1713 with the Treaty of Utrecht; the third was King George's War, which began in 1744 and ended in 1748; and the fourth was the French and Indian War (also known as the Seven Years War), which 
began in 1754 and ended in 1763 (Waselkov 2001:8-11). These wars waged in North America coincided with wars being fought in Europe between the same nations.

Fortunately for the French Crown, it had Sébastien Le Prestre de Vauban at its disposal. After having served as a soldier in Louix XIV's army, Vauban was awarded a commission (among other honors) and began working as a military architect, designing fortifications. Vauban, given the duty of designing and building fortifications all over France, designed more than thirty forts, and fortified and strengthened walled towns (Katz 2004:21). Among his most notable is La Citadel Vauban, at Belle-Ile-en-Mer, Brittany; this massive star-shaped fort was constructed of stone and finished in 1674 (Katz 2004:21). The enthusiasm by French military planners for Vauban's designs was echoed by a similar enthusiasm by colonizers; Heldman (1991) writes that Vauban established a corps of military engineers, some of whom traveled to North America, bringing along plans for elaborate fortifications as well as those for four-bastioned frontier forts (Heldman 1991:208-209).

Vauban's forts were characteristically star-shaped, with bastions at the corners. Whereas traditional European fortresses' straight or convex exterior walls afforded defenders within the forts no clear lines-of-sight along the exterior walls (and thus allowed attackers near), Vauban's plans instead featured either concave exterior walls, or straight walls with bastions jutting out beyond the corners, and afforded defenders clear lines-of-sight along the exterior walls (and thus kept attackers at a distance).

Additionally, the walls were slit, allowing the defenders to fire at the attackers with relative safety. 
The importance of establishing and maintaining military presences in the Mississippi Valley, from the Great Lakes and the Illinois Country in the north to New Orleans in the south, was of primary importance to the French colonization effort in North America. As in other colonies, endeavor was focused on two goals: extracting, processing, and shipping natural resources; and the production, processing, and shipping of surplus agricultural goods (Keene 1991:40) In discussing the importance of forts in this enterprise, Walthall (1991) writes that the construction of forts was a primary objective of France in establishing its domination in its extensive new empire, and securing these areas against threats from the English and the Spanish (Walthall 1991:42). Following Vauban's principles of fortification, successive French colonial governments erected more than a dozen forts—ranging from temporary wooden stockades to massive stone fortifications - in the territory within the Louisiane colony (Walthall 1991:42).

It is also important to note that, while present-day military forts primarily serve the needs of military forces, French colonial forts in the New World served wider purposes. For example, both Fort Toulouse in Alabama and Fort de Chartres were administrative centers serving civil and military purposes; as Katz (2004) puts it: "They were a refuge against a savage wilderness" (Katz 2004:21).

One French colonial fort in North American to feature Vauban's concepts was Fort Michilimackinac, which was located on the southern shore of the Straits of Mackinac. Initial construction of the fort—originally known as "De Lignery's Fort"took place from 1715 to 1717 . In the 1730s the fort was expanded, and in 1744 the fort was repaired and expanded, again. The British took control of the fort in 1761, and held it until they relocated it to Mackinac Island during the winter of 1780-1781 (Sambrook 
1992:33). The fort's architectural design was that of a stockade fort, and similar to a Vauban-style fort. According to De Lignery's map and the Magra map, the fort's arrangement of walls does not suggest a star as much as it suggests a hexagon; its east and west limits feature straight walls which parallel to each other, while its north and south limits each feature a pair of walls which form an articulated convex wall (Sambrook 1992:38-40). Four bastions, one at each of the main corners, would have allowed defenders excellent lines-of-sight by which to aim at attackers; at the articulation point at the center of the other walls seem to be located emplacements, possibly for cannon. However, the 1749 Lotbiniere map suggests a more truly "Vauban" design—an elegantly simple, straight-walled square with four bastions, and a triangular "demilune" jutting out from two adjacent corners (Vauban 1968:26 [1740], 132-133 [1737]). Another fort, incidentally — the Fort at Pentagoet, in present day Maine — shares with Fort Michilimackinac a documentary record which is potentially as confusing as it is enlightening. Built on the site of a trading colony originally settled in 1629 by members of Britain's Plymouth Colony, the site passed into French control, and then back into British control. The documentary record - comprised of supply inventories, written descriptions of the fort, and plan drawings_-present archaeologists with a challenging site to interpret. As control of the site's fortifications passed from one political body to another-whether nation to nation, or commanding officer to commanding officerbuildings were replaced or reconstructed, and plans were altered (Faulkner and Faulkner: 1987:53-58).

Like that of Fort Michilimackinac, the history of Fort de Chartres, in the Illinois Country, is one of construction, repair, renovation and improvement. The first Fort de 
Chartres was constructed in 1721. Its architectural design was that of a square fort with two bastions; the construction method was wooden piles. In 1726 it was nearly destroyed by floodwaters; some sources suggest abandonment (Jelks et al. 1989:111). A period document notes fours bastions, suggesting that either two bastions had been added, or new (second) fort had been constructed. By the mid-1730s, the wooden fort was falling into disrepair, and it was abandoned by 1748. In 1754, a new (third) fort was constructed, the architectural design of which featured a square layout with four bastions. This time, however, the construction method was stone. As with Fort Michilimackinac, Fort de Chartres's design featured straight perimeter walls, with bastions positioned jutting far enough beyond the planes of the walls to afford defenders clear shots at attackers.

Another fort, Fort de l'Ascension—-later known as Fort Massiac (in some sources, this is Fort Massac)—was built in 1757; its design featured four 128' long walls (168' if including the four bastions), with a cannon emplacement overlooking the river (Richey 2007). The construction method featured two rows of stockaded tree trunks, joined together (Richey 2007). The fort was abandoned in 1764; and thirty years later, in 1794, the American army built a fort of same size on same site, which was used until 1814 (Richey 2007).

In summary, French colonists in North America used traditional French architectural designs to establish and maintain the control over indigenous populations that was crucial to the protection of trade and supply routes, and to create administrative centers serving civil and military purposes. The importance of establishing and maintaining military presences, and securing its extensive new empire against threats 
from the English and Spanish, was of primary importance to the French colonization effort in North America; and, to these ends, Vauban-trained military engineers traveled to North America with plans for elaborate fortifications. However, these forts also provided "a refuge against a savage wilderness" (Katz 2004:21) that would have been both familiar and welcome to military personnel, religious missionaries, fur traders, voyageurs (travelers, who primarily transported furs), coureurs des bois (runners of the woods, who were unlicensed trappers and fur traders), and settlers alike.

\section{Civil, Commercial, and Residential Architecture}

Archaeological artifacts, material culture, and historical documentation associated with French colonial residential and civic sites in North America, such as those in Ste. Genevieve and Cahokia, in the Illinois Country and the Mississippi River Valley indicate that French colonists in North America used traditional French architectural designs to transport French cultural traditions and recreate them in the colonies, and to maintain a sense of "Frenchness" through time. Additionally, French colonists altered traditional French home construction methods in order to adapt them to new physical and cultural environments.

While French colonial military leaders in North America were expected to utilize both the best and the latest architectural designs and construction methods when building forts - and were budgeted the funds and the manpower with which to accomplish such large-scale projects—civilians building civil, commercial, and residential buildings were freer to use more familiar, traditional French designs and methods. Additionally, civilians erecting buildings would have had comparatively limited funds and manpower with which to work. 
While Vauban's cutting-edge fort designs were being used in both France and North America to build military installation, traditional French designs and methods were being used throughout Nouvelle France. One common French vernacular architectural design used in both France and North America was the hipped roof-a roof where all four sides ran up at a slant (Edwards 2006:251). With a hipped roof, a house could have large eaves extending far enough out to cover wide galleries, or porches - another traditional French vernacular design element (Edwards 2006:251). Thin wood columns often supported the eaves. Framing was most often comprised of wooden timbers (columbage), and generally featured either poteaux-sur-solle (post-on-sill) or poteaux-enterre (posts-in-ground) (Edwards 2006:263). Spaces between the framing members would be in-filled with bousillage, a mixture of clay or mud with hair, grass, or moss, or bricks (Edwards 2006:264-5). Another in-fill was pierrotage, a mixture of lime mortar, clay, and small stones. Another feature of French vernacular houses was that the living quarters were often raised above ground level.

Extant French colonial buildings in the Illinois country offer glimpses of how traditional vernacular French designs and methods were implemented by colonists on the North American frontiers. The design of the Bauvais-Amoureux House in Ste. Genevieve, Missouri, for example, features poteaux-en-terre (posts-in-ground) construction. The designs of the Bolduc House and the Durand Cabin, both of which are in Ste. Genevieve, feature poteaux-sur-solle (posts-on-sill) construction. The Durand cabin also featured pierrotage in-fill between the framing members. The BequetteRibault House, also in Ste. Genevieve, boasts poteaux-en-terre (posts-in-ground) 
construction, along with the wide hipped roof, wooden columns supporting the roof trusses, wide galleries, and a raised floor.

The Cahokia Courthouse, in Cahokia, Illinois, features poteaux-sur-solle (postson-sill) construction, along with a wide hipped roof, wooden columns supporting the roof trusses, and wide galleries. The fact that the main floor is not raised may well be indicative of its function as a civic building, rather than as a dwelling (Koeper (1968:20).

Archaeological artifacts, material culture, and historical documentation associated with sites indicate that French colonists in North America adapted traditional French construction techniques to new physical environments and new cultural environments.

French colonists in North America adapted traditional French construction techniques in order to adapt them to new physical environments; such environments included those with different climates, geographies, and natural resources than France (Birk 1991; Gérin-Lajoie 1976; Gums et al. 1991; Halchin 1985; Hall 1991; Heldman and Minnerly 1977; Katz 2004; Keene 1991; Nassaney et al. 2002; Saucier and Seineke 1969; Seale et al. 2002; Stone 1972; Walthall 1991; Waselkov 1997). Additionally, French colonists in North America adapted traditional French construction techniques in order to adapt them to new cultural environments; such environments included those with populations of Native Americans, British, Germans, and Swiss (Birk 1991; Gums et al. 1991; Halchin 1985; Hall 1991; Katz 2004; Keene 1991; Nassaney et al. 2002; Seale et al. 2002; Stone 1972; Walthall 1991; Waselkov 1997).

For example, Fort Pentagoet, near modern-day Castine, Maine, was reconstructed by the French in 1635 to control the fur trade along the Penobscot River; construction largely consisted of stone, and included four Vauban-style bastions (Faulkner 1992:85- 
86). Additionally, excavations at Site $21 \mathrm{Mo} 20$, in Little Falls, Minnesota, suggest that a mid-eighteenth-century French colonial outpost there included a palisaded poteaux-enterre wall (Birk 1991:257), and another structure the exterior walls of which also were built using the poteaux-en-terre construction method (Birk 1991:260). Furthermore, Edwards (2006), writing about the failure, during the period of 1699-1730, of poteauxen-terre and poteaux-sur-solle construction methods in Lower Louisiana's heat and humidity, points out that environmentally-suitable alternative methods quickly had to be established (Edwards 2006:267). French architects and engineers adapted architectural designs from the northern, cooler climate of France, to the warmer, more humid climate of New Orleans (Edwards 2006:267). Because enslaved Africans were the primary source of labor in Lower Louisiana during this era, the traditional French methods employed had to be quickly and readily learned by the slaves under the extreme frontier conditions; and construction methods in the South were likely altered to be more understandable and executable by slaves working under such conditions (Edwards 2006:267). Because these builders, trained in West African and West Indian building methods, were familiar with building methods similar to bousillage and poteaux-en-terre, it was perhaps natural that bousillage-entre-poteaux-sur-solle (mud between posts on a sill) became the most-used wall construction method Lower Louisiana countryside (Edwards 2006:267). Even after these methods had been replaced, the builders utilized them in new construction on the frontier; Edwards argues that this only makes sense; less-than-ideal circumstances on the frontier would have provided very convincing arguments to revert to tried-and-true ways (Edwards 2006:267). 
The historical and archaeological record includes evidence of the adaptations of traditional French construction techniques made by French colonists in North America in order to adapt them to new physical and cultural environments. This study seeks to understand whether those physical environmental factors (e.g., species of wood used, local availability of stone, climatic humidity, flooding frequency, etc.) made a difference in the choice to utilize poteaux-en-terre or poteaux-sur-solle construction methods.

\section{Summary}

This discussion has shown that French colonists in North America used architectural design in military buildings to establish and maintain control over indigenous populations. Examples of this are the Vauban-style, star-shaped, bastioned fort, which afforded protected sight lines toward the enemy; and the fact that these forts were monumental, whether wood or stone, and constituted what must have seemed to both Native Americans and colonists from other European countries "permanent" presences. This discussion has also shown how French colonists used architectural design in military buildings to transport French cultural traditions and recreate them in the colonies. Historical documents make clear that such forts afforded protection for civilians, traders, and military personnel alike; by the construction and maintenance of such forts, French traditions of territorial defense, military strength, and control of land and trade routes were replicated in the New World.

This discussion has also addressed how adaptations were made to new physical environments. While French forts in France were constructed using quarried stone, most French forts in North America were constructed using wood, which was much more plentiful and inexpensively had than stone. (However, there were exceptions; both 
Fortress Louisbourg and the fourth Fort de Chartres were constructed of stone.)

Additionally, if a strategic French wooden fort in North America was destroyed by flood, it could either be repaired cheaply with wood, or rebuilt with stone. Also, methods of building French forts in North America were adapted to new cultural environments; while French forts in France were constructed using quarried stone, French forts in North America were usually constructed using wood.

This discussion has also shown that French colonists in North America used architectural design in civic and residential buildings to transport French cultural traditions and recreate them in the colonies. Examples of this were the inclusion of hipped roofs, long eaves, wide galleries, and raised living spaces. It was through the use of these design elements that French colonists - whether in the Northeast, the Southeast, or the Mississippi Valley_were able to maintain a sense of "Frenchness" through time. Additionally, the resourcefulness and ability to recreate cultural traditions in the New World allowed for the maintenance of French identity.

This discussion has also shown how French colonists in North America altered traditional construction methods to suit local environments. These alterations took place for two primary reasons. The first reason was to adapt the methods to new physical environments. Examples of this are the substitutions of local woods for stone or traditional French woods, and the use of local materials for bousillage and pierrotage.

Because colonial enterprises in the New World left marks, both in the ground and on the landscape, archaeologists and historians are yet able to study the buildings, and what they would have meant to those colonists who built them. Whether those colonists were coming to the New World from Europe or Asia, and whether they were coming to 
escape persecution or to exploit opportunities, they would have brought with them cultural memories and conceptions which, when realized through architectural designs and building methods, helped them to create buildings and spaces with familiar cultural elements in a new place. 


\section{CHAPTER III METHODOLOGY}

This chapter will present descriptions of the buildings used in this study. Next, the analytical methods used in this study will be explained. Finally, the construction dates for the poteaux-en-terre buildings and the poteaux-sur-solle buildings used in this study will be presented.

\section{Descriptions of the Buildings Used in This Study}

Structures in Natchitoches Parish, Louisiana

The Badin-Roque House (1770) was initially occupied by Jean Baptiste Metoyer; it is one of the few remaining poteaux-en-terre structures in the United States (Louisiana Regional Folklife Program n.d.; Seale et al. 2002:105). The associated Badin-Roque House Kitchen (1770) is of the poteaux-sur-solle construction method (Seale et al. 2002:105).

The Fort des Natchitoches chapel was located in present-day Natchitoches Parish, Louisiana. It is depicted on a 1733 plan of Natchitoches Fort as a poteaux-en-terre structure (Walthall and Benchley 1987:26-27). It was constructed after the original Fort St. Jean Baptiste de Natchitoches has fallen into disrepair and was abandoned, when the replacement fort was constructed on Musler's Hill (“Hauter a Musler")—a twenty foot bluff overlooking a channel of the Red River (Gould et al 2002:13-14). 


\section{Structures in New Orleans, Louisiana}

The Gabriel Peyroux House (1780) was moved from its original setting to its present location in about 1780 . According to period documents, the structure was moved and reconstructed by Maurice Milon for Gabriel Peyroux de la Roche Molive (Toledano and Christovich 1980:32-33). Although exhibiting brique-entre-poteaux construction, the structure was - both in its initial form and its present form — lifted on piers (Toledano and Christovich 1980:32-33). Because such construction would require the posts to be resting upon sills, it is being included in this study as exhibiting characteristics of a poteaux-sur-solle structure.

\section{Structures in Old Mobile (1MB94), Mobile County, Alabama}

A number of structures were identified during archaeological excavations in Old Mobile (1MB94), Mobile County, Alabama. All are dated, in the archaeological reports used for this study, to about 1702-1711.

Old Mobile (1MB94) Structure 01, excavated in 1989, was determined to have been built using poteaux-sur-solle construction (Gums 2002:20; The Digital Archaeological Record 2004a). The artifact assemblage associated with this structure led project archaeologists to interpret it as having served as a private residence (Gums 2002:20; The Digital Archaeological Record 2004a).

Old Mobile (1MB94) Structure 02, excavated in 1990, was located at the western edge of the main townsite, adjacent to a swamp area (The Digital Archaeological Record 2004b). A blacksmith's work area, with a forge and an associated shelter were identified; surrounded the compound was a complex of fence footing trenches, identified as palisade-style fences that were built and rebuilt frequently during Old Mobile's 
occupation (The Digital Archaeological Record 2004b). This study is including this structure's complex of fences as an example of the poteaux-en-terre construction method.

Old Mobile (1MB94) Structure 03, excavated in 1991-1992, initially was identified as an earthen floor in an unplowed, wooded area along the western edge of the town site (Gums 2002:20; The Digital Archaeological Record 2004c). Although pieuxen-terre (stakes-in-ground) wall foundation trenches appear to have ultimately replaced decayed sills, the two-room structure was initially constructed built using the poteauxsur-solle method (Gums 2002:20; The Digital Archaeological Record 2004c).

Old Mobile (1MB94) Structure 04, identified during excavations in 1991-1992 and 2013, also initially was identified as an earthen floor in an unplowed, wooded area along the western edge of the town site (The Digital Archaeological Record 2004d). The structure was constructed using the poteaux-en-terre style; excavations also revealed evidence of an interior brick hearth (The Digital Archaeological Record 2004d).

Old Mobile (1MB94) Structure 05, identified during excavations in 1991, also initially was identified as an earthen floor in an unplowed, wooded area. The structure was identified as having been constructing using the poteaux-sur-solle method (Gums 2002:20; The Digital Archaeological Record 2004e).

Old Mobile (1MB94) Structure 14, initially was identified as an earthen floor in an often-flooded, unplowed area nearby to the center of the town site, was intermittently excavated from 1992 until 2003 (The Digital Archaeological Record 2004f). The structure was identified as having been constructed using the poteaux-en-terre method. The associated artifact assemblage contains a wide array of serving vessels, and as such 
indicates possible usage of the building as an inn or a tavern (The Digital Archaeological Record 2004f).

Old Mobile (1MB94) Structure 30, excavated between 1992 and 1996, was interpreted as a two-room building constructed in the pieux-en-terre style in about 1706 (Gums 2002:19-23; The Digital Archaeological Record 2004g). The usage/occupation sequence has been interpreted by project archaeologists as having initially been used as a military barracks, and afterwards serving as a storehouse secured by the palisade-type fence encircling the building (Gums 2002:19-23; The Digital Archaeological Record 2004g).

Old Mobile (1MB94) Structure 31, excavated from 1996 to 2002, was interpreted as a one-room building constructed in the pieux-en-terre style in about 1706 for use as a military barracks (Gums 2002:19-23; Gums and Shorter 2004). Project archaeologists identified preserved subsurface wall trenches below the plowzone, a doorway in the middle of the southwest wall, and an indication of a bread oven platform and hearth feature (Gums 2002:19-23; Gums and Shorter 2004).

Old Mobile (1MB94) Structure 32, excavated intermittently from 1996 until 2007, was interpreted as a duplex-type building constructed in the pieux-en-terre style, begun in about 1706 for use as a military barracks (Gums 2002:19-23; Gums 2004). As with Structure 31, archaeologists identified a preserved subsurface wall trench below the plowzone; this feature was interpreted as having served as a bread oven platform and hearth feature (Gums 2002:19-23; Gums 2004). 


\section{Structures in Cahokia, Illinois}

The Fort de Chartres II barracks and the Fort de Chartres II forge were located in Cahokia, Illinois. Historical documents date both structures to 1725 , and indicate that both were constructed using the poteaux-sur-solle method (Walthall and Benchley 1987:27). Neither structure is extant.

The River L'Abbe Chapel was located in Cahokia, Illinois. Although little is known of this structure from period historical sources, later documents state that the circa 1735 chapel was built by French colonists to support missionary efforts directed at the Cahokia Indians - a branch of the larger Illini tribe (Walthall and Benchley 1987:10). Later land records indicate that the chapel was constructed on the first terrace of Monks Mound, about nine miles from the French village situated near the confluence of Cahokia Creek and Canteen Creek; and although documents do not record when the chapel was abandoned, a date of 1752 is suggested by contemporary accounts of a retributive massacre of the Illini by 1,000 Sious, Sauk, Kickapoo, and Fox warriors (Walthall and Benchley 1987:11-12). Archaeological excavations were conducted during 1968, 1969, and 1971 by University of Wisconsin (Milwaukee) field crews supervised by Elizabeth D. Benchley and directed by Melvin L. Fowler (Walthall and Benchley 1987:12). Excavation plans indicate that this structure was constructed using a combination of poteaux-en-terre and poteaux-sur-solle methods (Walthall and Benchley 1987:27).

The Cahokia Courthouse, in Cahokia, Illinois, a present-day reconstruction of an original structure dating to 1740 , features poteaux-sur-solle (posts-on-sill) construction, along with a wide hipped roof, wooden columns supporting the roof trusses, and wide galleries. The fact that the main floor is not raised may well be indicative of its function 
as a civic building, rather than as a dwelling. Koeper (1968), writes that the poteaux-sursole was a modification of poteaux-en-terre, that the wood used locally was usually cedar, and that the palisade log construction resembles French Norman building (1968:20). Koeper also notes that, while Cahokia Courthouse presently has a shingle roof, this feature probably replaced an earlier thatched roof (1968:20).

Although the Nicolle House (also known as the Nicolle/Meunier house) is no longer extant, information about it is available via both historical documentation and archaeological investigations. The structure was constructed about 1759-1765 by the Nicolle family, which occupied it from at least 1766 until 1779. The house had a few short-term owners after the Nicolle family, until J. Meunier occupied it from 1794 until at least 1809; and the structure was no longer extant in 1841 (Gums 1988:247-248). Its archaeologically-derived structural remains, excavated during archaeological investigations at the Cahokia Wedge site, are interpreted as exhibiting poteaux-en-terre construction (Walthall and Emerson 1991:112). In writing about the structure, Gums states,

The French colonial houses were typically made of handhewn logs of locally available wood; generally those resistant to rot such as mulberry and cedar were sought. Building construction was predominantly of poteaux-en-terre (posts in the earth) or poteaux-sur-solle (posts on sill) styles. Usually the houses had whitewashed exteriors and porches or galleries on all four sides. The excavated Nicolle/Meunier structure was most likely a typical house in Cahokia and probably resembled those illustrated in the 1841 lithograph by J. C. Wild, as well as the numerous French colonial houses which are today located in the Historic District of Ste. Genevieve, Missouri. (1988:11)

The Langedoc House (also known as the Duckhouse Site) is no longer extant; information about it is available as a result of archaeological investigations conducted jointly by Sangamo Archaeological Center and the University of Illinois in 2006. These 
investigations encountered remains of what was interpreted to have been a circa-1760 French dwelling that featured poteaux-sur-solle construction techniques; also present were yard-area pits, as well as what is interpreted to have been a circa-1730 aboriginal house basin predating the French occupation (Mazrim n.d.). The building likely was occupied by merchant Joseph Languedoc, who might also have used it as his store before abandoning it around 1800 (Mazrim n.d.).

The Gammon Site also is no longer extant; information about it is available as a result of archaeological investigations conducted jointly by Sangamo Archaeological Center and the University of Illinois in 2007. These investigations encountered remains of what was interpreted to have been a circa-1740 French dwelling that featured poteauxen-terre construction techniques; the building had a sub-floor cellar, as well as a stone fireplace (Mazrim n.d.). The site is believed to have been abandoned about 1790 (Mazrim n.d.).

Structures in Prairie du Pont, Illinois

The Martin-Boismenue House, still extant in what is now East Carondelet, Illinois, was constructed in about 1790 using the poteaux-sur-solle construction method (Walthall and Emerson 1991:115). Although historical renovations have impacted the integrity of the original architecture (e.g., the probable replacement of a gallerie with a smaller porch, 1888; and a kitchen addition, 1913), archaeological investigations directed primarily by the Cahokia Archaeological Society and conducted between 1981 and 1983 identified the gallerie as a part of the original construction plan (Walthall and Emerson 1991:115-119). 
Structures in Ste. Genevieve, Missouri

The Bequette-Ribault House, still extant in Ste. Genevieve, was constructed in 1780 using the poteaux-en-terre construction method; its posts are of cedar wood (Ekberg 1996:287). Although Ekberg describes this house as "smaller," it is also described as an excellent example of a two-room French colonial house with a fireplace in each room and galleries on all four sides (Ekberg 1996:292).

The Louis Bolduc (pére) House was built in 1792 by merchant Louis Bolduc, a merchant with concerns in the lead mines to the west of Ste. Genevieve. This structure was built using the poteaux-sur-solle method of construction. Although Bolduc previously had built a home in Old Town in 1770, Ekberg questions whether the condition of that earlier house's components, having been subjected to the repeated flooding that drove settlers to found New Town, would have allowed for any reuse whatsoever; the author suggests that the new house was probably constructed of new components (Ekberg 1996:441).

The Vital Ste. Gemme Beauvais House I was constructed in about 1792; it is one of the few extant poteaux-en-terre structures (Ekberg 1996:442). The builder, Beauvais, had left Kaskaskia with his family and slaves in about 1787; first settling in Saline, by 1792 he had settled in New Ste. Genevieve (Ekberg 1996:442).

The Beauvais-Amoureux House was built by Jean-Baptiste St. Gemme Bauvais in about 1792 along St. Mary's Road in Ste. Genevieve using the poteaux-en-terre construction method (Ekberg 1996:442). 
The Janis-Ziegler House was constructed about 1790 using the poteaux-sur-solle construction method (Ekberg 1996:441). Although historically, it was subjected to Victorianization, presently it is undergoing restoration efforts.

The Datchurut House, no longer extant, was built in "Old Town"- that is, the first settlement named Ste. Genevieve—probably about 1766 by Jean Datchurut, a wealthy merchant who had come to North America from France (rather than by way of Canada) (Ekberg 1996:287). Datchurut was a wealthy merchant, rather than a farmer, and had no family. Perhaps as a consequence of his uniqueness in Ste. Genevieve, his house was also unique: It was long and narrow, and featured poteaux-en-terre construction on one side and poteaux-sur-solle construction on the other side (Ekberg 1996:287).

\section{Structures at Fort Michilimackinac, Michigan}

The Fort Michilimackinac forge, no longer extant, is believed to have been built initially in the early 1730 s using poteaux-en-terre construction.

House One (part of the South-Southeast Row House), no longer extant, was built initially in the early 1730s using poteaux-en-terre construction, and was rebuilt in the same style in the mid-1760s. It was occupied by French fur traders (Heldman 1978).

House A and House B (part of the Southeast Row House), no longer extant, were built in the early 1730s using poteaux-en-terre construction, and were rebuilt and combined as a single house ("House A-B") in the same style in the mid-1760s. Each of the structures was occupied by French fur traders (Heldman 1977; Heldman and Grange 1981).

House C (part of the Southeast Row House), no longer extant, was built in the early 1730s using poteaux-en-terre construction, and was rebuilt in the same style in the 
mid-1760s. The structure was occupied by a French family the head of which was a voyageur - and possibly a fur trader (Halchin 1985).

House D (part of the Southeast Row House), no longer extant, was built in the early 1730s using poteaux-en-terre construction, and was rebuilt in the same style in the mid-1760s. The structure was occupied by a French fur-trading family (Evans 2001).

\section{Analytical Methods}

During my research, I examined historical archaeologists' and historians' descriptions, discussions and interpretations of historical documents, archaeological artifacts, material culture, and extant structures relating to the conceptualization and realization of French colonial structures built in North America. Because all of the sources, whether focusing on military, civic, commercial, or residential structures, presented details about how buildings were designed, how buildings were constructed, or both, the subject areas of interest resolved themselves into two categories: architectural designs and construction methods.

For the purposes of my research, the architectural designs category deals with the use and arrangement of both building elements (e.g., roofs, eaves, walls, floors, fences, palisade walls, etc.) and activity areas (e.g., rooms, porches, bastions, etc.). The construction methods category deals with the materials used in the creation of those elements (e.g., stone, wood, mud, clay, straw, etc.) and with the creation of those building elements (e.g., physical execution of design elements, building procedures, etc.).

To answer the research questions I obtained and reviewed archaeologically derived data from published and unpublished reports of historical archaeological sites known (or believed) to have had French vernacular buildings. Any architecture, whether 
intended for civic, ceremonial, or private use, and whether built by representatives of the Church, the Crown, or by entrepreneurs or private citizens, was reviewed. In a word, I obtained and conducted a review of reports of archaeologically dated and extant buildings. Data were put into a Microsoft Excel spreadsheet; the fields (columns) included: building name, settlement location, geographical setting (e.g., lake/ocean coast, raised elevation, or river shore/floodplain), method of construction (e.g., poteaux-enterre, or poteaux-sur-solle). I then figured the mean, median, mode, and range of construction dates for each type of construction, and determined whether or not temporal and geographical patterns existed.

Archaeological evidence of construction techniques was analyzed for northern Michigan (Evans 2001; Halchin 1985; Heldman 1977, 1978; Heldman and Minnerly 1977; Stone 1972); Acadia (Faulkner 1992; Faulkner and Faulkner 1987); the middle Mississippi Valley (Gums 1998; Gums et al. 1991; Hall 1991; Keene 1991; Mazrim, n.d.; Thurman 1984; Walthall 1991; Walthall and Benchley 1987); and Lower Louisiana (Beavers 1983; Dawdy 2000; The Digital Archaeological Record 2004a-2004g; Lamb 1983; Markell et al. 1999; Maygarden 2006; Mueller and Newkirk, 1981; Walker 1971; Waselkov 2001; Waselkov and Gums 2000).

Data were organized by geographical setting (i.e., situated on a lake/ocean coast, at a raised elevation, or on a river shore/floodplain), and by settlement location (e.g., at New Orleans, Louisiana; Cahokia, Illinois; Ste. Genevieve, Missiouri; etc.).

Where the available literature for a structure indicated a range of possible dates of construction, I used the median date of the stated range. Although this seemed arbitrary, 
it was no more or less so than it would have been to have used either the beginning date in the range or the ending date in the range.

Because the River L'Abbe Chapel and the Durand Cabin are described in the source materials as exhibiting characteristics of both poteaux-en-terre construction methods and poteaux-sur-solle construction methods, I included each structure both in the poteaux-en-terre category and in the poteaux-sur-solle category. Upon reflection, I could have chosen to include either structure in a single category. Alternately, I could have chosen to include data analyses resulting from including both structures in both categories, as well as data analyses resulting from including either structure in a single category. In the case of the Datchurut House - portions of which were build using both methods-I chose to include the structure both in the poteaux-en-terre category and in the poteaux-sur-solle category. When it comes to cases of methodology such as this, I can only recommend keeping all data visible, and including clear explanations about one's methodology.

\section{Construction Dates for the Poteaux-en-Terre Buildings}

For the data analysis of the poteaux-en-terre buildings, I used the following construction dates (note that the dates in parentheses represent the median for the immediately preceding date range, where appropriate, as previously described): Old Mobile (1MB94) Structure 02, 1707 (the date range was 1702-1711); Old Mobile (1MB94) Structure 04, 1707 (the date range was 1702-1711); Old Mobile (1MB94) Structure 14, 1707 (the date range was 1702-1711); Old Mobile (1MB94) Structure 30, 1707 (the date range was 1702-1711); Old Mobile (1MB94) Structure 31, 1707 (the date range was 1702-1711); Old Mobile (1MB94) Structure 32, 1707 (the date range was 
1702-1711); Fort Michilimackinac forge, 1715; Fort Michilimackinac House One, 1730;

Fort Michilimackinac House A, 1730; Fort Michilimackinac House B, 1730; Fort Michilimackinac House C, 1730; Fort Michilimackinac House D, 1730; Fort des Natchitoches chapel, 1733; River L'Abbe Chapel, 1735; Gammon Site, 1740; Nicolle/Meunier, 1762 (the date range was 1759-1765); Badin-Roque House, 1770; Bequette-Ribault House, 1780; Vital Ste. Gemme Beauvais House I, 1792; BeauvaisAmoureux House, 1792.

\section{Construction Dates for the Poteaux-sur-Solle Buildings}

For the data analysis of the poteaux-sur-solle buildings, I used the following construction dates (note that the dates in parentheses represent the median for the immediately preceding date range, where appropriate, as previously described): Old Mobile (1MB94) Structure 01, 1707 (the date range was 1702-1711); Old Mobile (1MB94) Structure 03, 1707 (the date range was 1702-1711); Old Mobile (1MB94) Structure 05, 1707 (the date range was 1702-1711); Fort de Chartres II barracks (1725); Fort de Chartres II forge (1725); River L'Abbe Chapel (1728-1732); Cahokia Courthouse, 1740; Langedoc House (1760); LaSource-Durand Cabin (1766); Badin-Roque House Kitchen (1770); Gab. Pey. de La Roche House (1780); Martin-Boismenue House (1790); Janis-Ziegler House (1790); and Louis Bolduc House (1792).

\section{Summary}

This chapter has presented brief descriptions of the buildings used in this study, and has explained the analytical methods used. Additionally, the construction dates for the poteaux-en-terre buildings and the poteaux-sur-solle buildings used in this study have been presented. 


\section{CHAPTER IV}

\section{DATA ANALYSIS AND INTERPRETATION}

This chapter will provide the data analysis for the chronology of construction dates and geographical settings for the poteaux-en-terre and poteaux-sur-solle structures used in this study, and the chronology of settlement location. Following this section, the interpretations of these data sets will be presented.

The range of construction dates for the poteaux-en-terre structures in this study is 85 years (1707-1792); and the range of construction dates for the poteaux-sur-solle structures in this study is 85 years (1707-1792). Additionally, the geographical setting of each poteaux-en-terre structure and each poteaux-sur-solle structure is classified as being situated on a lake/ocean coast, at a raised elevation, or on a river shore/floodplain.

\section{Data Analysis: Chronology of Construction Techniques}

Mean Construction Date for Poteaux-en-Terre Structures

The mean construction date for the poteaux-en-terre structures in this study (Table 1) is derived by dividing the sum of the construction dates by the number of the construction dates. The sum of the construction dates is 36,477 . This sum, 36,477, divided by the number of the construction dates, 21 , equals 1,737 . Therefore, the mean construction date for the poteaux-en-terre structures in this study is 1737 . 
Table 1. Poteaux-en-Terre Structures Studied, Ordered by Geographical Setting (column) and by Date of Construction (row)

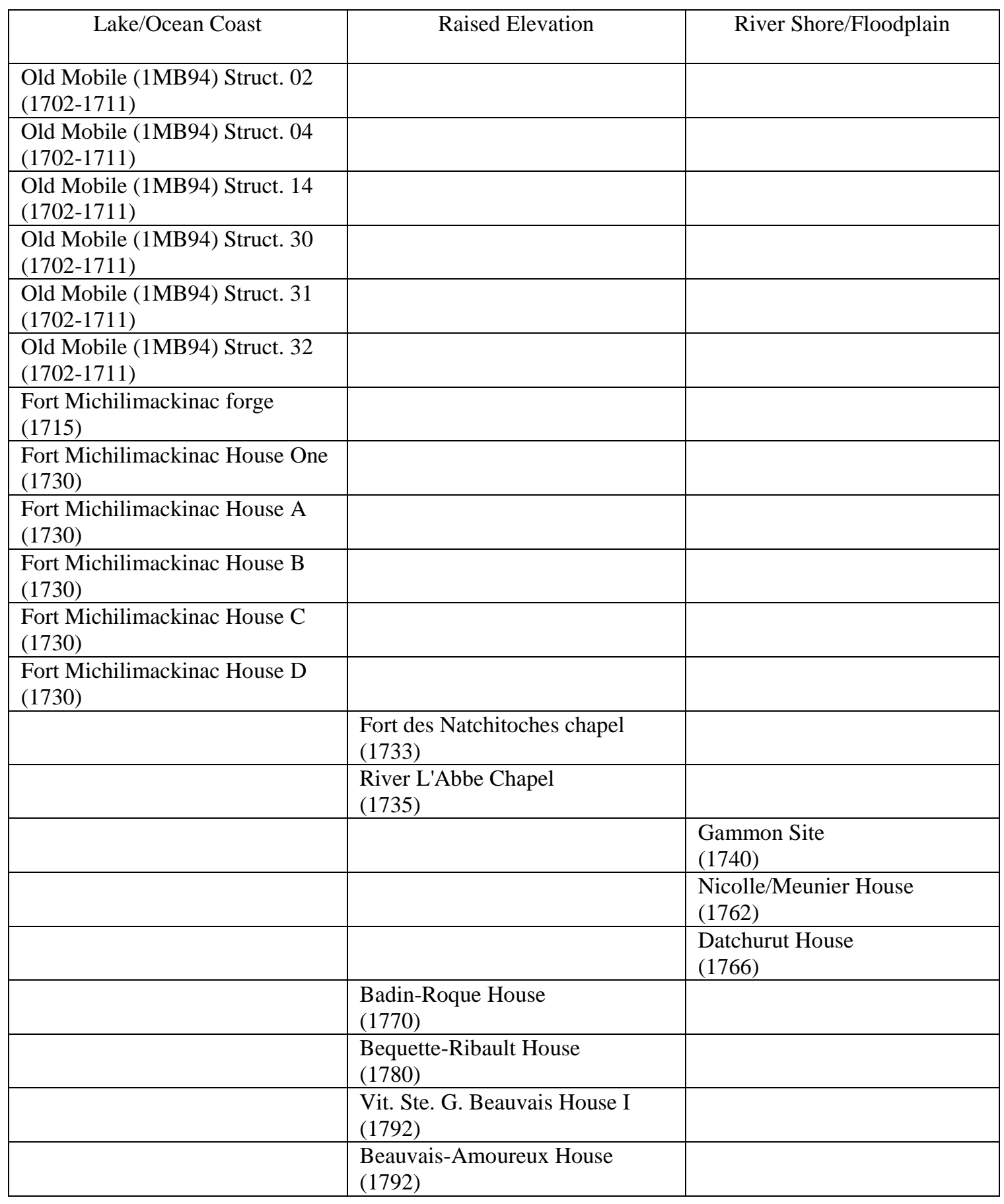




\section{Median Construction Date for Poteaux-en-Terre Structures}

The median construction date for the poteaux-en-terre structures in this study (Table 1) is derived by organizing the construction dates into an ordered list, and identifying the middle construction date. Therefore, the median construction date for poteaux-en-terre structures in this study is 1730.

\section{Mode Construction Date for Poteaux-en-Terre Structures}

The mode construction date for the poteaux-en-terre structures in this study (Table 1) is derived by identifying the most often-repeated construction date. The most often-repeated construction date is 1707 . Therefore, the mode construction date for the poteaux-en-terre structures in this study is 1707.

Range of Construction Dates for Poteaux-en-Terre Structures

The range of construction dates for the poteaux-en-terre structures in this study (Table 1) is 85 years (1707-1792).

Mean Construction Date for Poteaux-sur-Solle Structures

The mean construction date for the poteaux-sur-solle structures in this study (Table 2) is derived by dividing the sum of the construction dates by the number of the construction dates. The sum of the construction dates is 26,260 . This sum, 26,260, divided by the number of the construction dates, 15 , equals $1,750.667$. Therefore, the mean construction date for poteaux-sur-solle structures in this study is 1751 . 
Table 2. Poteaux-sur-Solle Structures Studied, Ordered by Geographical Setting (column) and by Date of Construction (row)

\begin{tabular}{|c|c|c|}
\hline Lake/Ocean Coast & Raised Elevation & River Shore/Floodplain \\
\hline \multicolumn{3}{|l|}{$\begin{array}{l}\text { Old Mobile (1MB94) Struct. } 01 \\
(1702-1711)\end{array}$} \\
\hline \multicolumn{3}{|l|}{$\begin{array}{l}\text { Old Mobile (1MB94) Struct. } 03 \\
(1702-1711)\end{array}$} \\
\hline \multicolumn{3}{|l|}{$\begin{array}{l}\text { Old Mobile (1MB94) Struct. } 05 \\
(1702-1711)\end{array}$} \\
\hline & $\begin{array}{l}\text { Fort de Chartres II barracks } \\
(1725)\end{array}$ & \\
\hline & $\begin{array}{l}\text { Fort de Chartres II forge } \\
(1725)\end{array}$ & \\
\hline & $\begin{array}{l}\text { River L'Abbe Chapel } \\
(1735)\end{array}$ & \\
\hline & $\begin{array}{l}\text { Cahokia Courthouse } \\
(1740)\end{array}$ & \\
\hline & & $\begin{array}{l}\text { Langedoc House } \\
(1760)\end{array}$ \\
\hline & $\begin{array}{l}\text { LaSource-Durand Cabin } \\
\text { (1766) }\end{array}$ & \\
\hline & & $\begin{array}{l}\text { Datchurut House } \\
(1766)\end{array}$ \\
\hline & $\begin{array}{l}\text { Badin-Roque House Kitchen } \\
(1770)\end{array}$ & \\
\hline & & $\begin{array}{l}\text { Gab. Pey. de La Roche House } \\
\text { (1780) }\end{array}$ \\
\hline & & $\begin{array}{l}\text { Martin-Boismenue House } \\
(1790)\end{array}$ \\
\hline & $\begin{array}{l}\text { Janis-Ziegler House } \\
(1790)\end{array}$ & \\
\hline & $\begin{array}{l}\text { Louis Bolduc House } \\
\text { (1792) }\end{array}$ & \\
\hline
\end{tabular}

\section{Median Construction Date for Poteaux-sur-Solle Structures}

The median construction date for the poteaux-sur-solle structures in this study (Table 2) is derived by organizing the construction dates into an ordered list, and identifying the middle construction date. Therefore, the median construction date for the poteaux-sur-solle structures in this study is 1760. 


\section{Mode Construction Date for Poteaux-sur-Solle Structures}

The mode construction date for the poteaux-sur-solle structures in this study (Table 2) is derived by identifying the most often-repeated construction date. The most often-repeated construction date is 1707 . Therefore, the mode construction date for the poteaux-sur-solle structures in this study is 1707 . Range of Construction Dates for Poteaux-sur-Solle Structures

The range of construction dates for the poteaux-sur-solle structures in this study (Table 2) is 85 years (1707-1792).

\section{Data Analysis: Geographical Setting}

Geographical Settings of Poteaux-en-Terre Structures

The geographical settings for the 21 poteaux-en-terre structures in this study include 12 , or 57.14 percent, situated on a lake/ocean coast; six, or 28.57 percent, situated at a raised elevation; and three, or 14.29 percent, situated on a river shore/floodplain (Table 1).

The 12 poteaux-en-terre structures in this study situated on a lake/ocean coast include the Old Mobile (1MB94) Structures 02, 04, 14, 30, 31, and 32 (all 1702-1711); the Fort Michilimackinac forge (1715), the Fort Michilimackinac House One (1730), Fort Michilimackinac House A (1730), Fort Michilimackinac House B (1730), Fort Michilimackinac House C (1730), and Fort Michilimackinac House D (1730) (Table 1).

The six poteaux-en-terre structures in this study situated at a raised elevation include the Fort des Natchitoches chapel (1733); the River L'Abbe Chapel (1735); the Badin-Roque House (1770); the Bequette-Ribault House (1780); the Vital Ste. Gemme Beauvais House I (1792); and the Beauvais-Amoureux House (1792) (Table 1). 
The three poteaux-en-terre structures in this study situated on a river shore/floodplain include the Gammon Site (1740), the Nicolle/Meunier House (17591765), and the Datchurut House (1766) (Table 1).

Geographical Settings of Poteaux-sur-Solle Structures

The geographical settings for the 15 poteaux-sur-solle structures in this study include three, or 20.00 percent, situated on a lake/ocean coast; eight, or 53.33 percent; situated at a raised elevation; and four, or 26.67 percent, situated on a river shore/floodplain (Table 2).

The three poteaux-sur-solle structures in this study situated on a lake/ocean coast include the Old Mobile (1MB94) Structures 01, 03, and 05 (all 1702-1711) (Table 2).

The eight poteaux-sur-solle structures in this study situated at a raised elevation include the Fort de Chartres II barracks and forge (both 1725); the River L'Abbe Chapel (1728-1732); the Cahokia Courthouse (1740); the LaSource-Durand Cabin (1766); the Badin-Roque House Kitchen (1770); the Janis-Ziegler House (1790); and the Louis Bolduc House (1792) (Table 2).

The four poteaux-sur-solle structures in this study situated on a river shore/floodplain include the Langedoc House (1760); the Datchurut House (1766); the Gabriel Peyroux de La Roche House (1780); and the Martin-Boismenue House (1790) (Table 2).

\section{Data Analysis: Chronology of Settlement Location}

The settlement locations for the construction of nine of the structures in this study — the Old Mobile (1MB94) Structures 01, 02, 03, 04, 05, 14, 30, 31, and 32 (all 1702-1711) —were at Old Mobile (1MB94), Mobile County, Alabama. All structures 
were situated on a lake/ocean coast. Both the mean and median construction dates are 1707 (Table 3).

Table 3. Mean and Median Construction Dates for Structures Studied in Old Mobile (1MB94), Mobile County, Alabama, Ordered by Geographical Setting (column)

\begin{tabular}{|c|c|c|c|}
\hline & Lake/Ocean Coast & Raised Elevation & River Shore/Floodplain \\
\hline Mean & 1707 & & \\
\hline Median & 1707 & & \\
\hline
\end{tabular}

The settlement locations for the construction of six of the structures in this study - the Fort Michilimackinac forge (1715), House One (1730), House A (1730), House B (1730), House C (1730), and House D (1730)—were at the Straits of Mackinac, at the northern tip of the lower peninsula of Michigan, nearby to present-day Mackinaw City. All structures were situated on a lake/ocean coast. The mean construction date is 1728 , and the median construction date is 1730 (Table 4).

Table 4. Mean and Median Construction Dates for Structures Studied in Fort Michilimackinac, Michigan, Ordered by Geographical Setting (column)

\begin{tabular}{|c|c|c|c|}
\hline & Lake/Ocean Coast & Raised Elevation & River Shore/Floodplain \\
\hline Mean & 1727.5 & & \\
\hline Median & 1730 & & \\
\hline
\end{tabular}

The settlement locations for the construction of seven of the structures in this study - the Fort de Chartres II barracks (1725), the Fort de Chartres II forge (1725), the River L'Abbe Chapel (1735), the Gammon Site (1740), the Cahokia Courthouse (1740), the Langedoc House (1760), and the Nicolle/Meunier house (1762)—were nearby to present-day Cahokia, Illinois. Four of the structures were situated on a raised elevation. The mean construction date for these is 1731 , and the median construction date is 1730 
(Table 5). Three of the structures were situated on a river shore/floodplain. The mean construction date for these is 1754 , and the median construction date is 1760 (Table 5). Table 5. Mean and Median Construction Dates for Structures Studied in Cahokia, Illinois, Ordered by Geographical Setting (column)

\begin{tabular}{|c|c|c|c|}
\hline & Lake/Ocean Coast & Raised Elevation & River Shore/Floodplain \\
\hline Mean & & & 1754 \\
\hline Median & & 1730 & 1760 \\
\hline
\end{tabular}

The settlement locations for the construction of three of the structures in this study - the Fort des Natchitoches chapel (1733), the Badin-Roque House (1770), and the Badin-Roque House Kitchen (1770) — is in present-day Natchitoches, Louisiana. All of the structures were situated on a raised elevation. The mean construction date for these structures is 1758 , and the median construction date is 1770 (Table 6).

Table 6. Mean and Median Construction Dates for Structures Studied in Natchitoches Parish, Louisiana, Ordered by Geographical Setting (column)

\begin{tabular}{|c|c|c|c|}
\hline & Lake/Ocean Coast & Raised Elevation & River Shore/Floodplain \\
\hline Mean & & & \\
\hline Median & & 1757.667 & \\
\hline
\end{tabular}

The locations for the construction of seven of the structures in this study- the LaSource-Durand Cabin (1766), the Datchurut House (1766) (at Old Ste. Genevieve), the Bequette-Ribault House (1780), the Janis-Ziegler House (1790), the Vital Ste. Gemme Beauvais House I (1792), and the Beauvais-Amoureux House (1792), and the Louis Bolduc (pére) House (1792)—were at Ste. Genevieve, Missouri. Six of the structures were situated on a raised elevation. The mean construction date for these is 1785 , and the median construction date is 1791 (Table 7). One of the structures was situated on a river 
shore/floodplain. Both the mean and median construction dates for this are 1766 (Table 7).

Table 7. Mean and Median Construction Dates for Structures Studied in Ste. Genevieve, Missouri, Ordered by Geographical Setting (column)

\begin{tabular}{|c|c|c|c|}
\hline & Lake/Ocean Coast & Raised Elevation & River Shore/Floodplain \\
\hline Mean & & & 1766 \\
\hline Median & & 1785.333 & 1766 \\
\hline
\end{tabular}

The location for the construction of one of the structures in this study- the Gabriel Peyroux House (1780)—was at New Orleans, Louisiana. It was situated on a river shore/floodplain. Both the mean and median construction dates for this are 1780 (Table 8).

Table 8. Mean and Median Construction Dates for Structures Studied in New Orleans, Louisiana, Ordered by Geographical Setting (column)

\begin{tabular}{|c|c|c|c|}
\hline & Lake/Ocean Coast & Raised Elevation & River Shore/Floodplain \\
\hline Mean & & & 1780 \\
\hline Median & & & 1780 \\
\hline
\end{tabular}

The location for the construction of one of the structures in this study - the Martin-Boismenue House (1790)—was nearby to present-day Prairie du Pont, Illinois. It was situated on a river shore/floodplain. Both the mean and median construction dates for this are 1790 (Table 9).

Table 9. Mean and Median Construction Dates for Structures Studied in Prairie du Pont, Illinois, Ordered by Geographical Setting (column)

\begin{tabular}{|c|c|c|c|}
\hline & Lake/Ocean Coast & Raised Elevation & River Shore/Floodplain \\
\hline Mean & & & 1790 \\
\hline Median & & & 1790 \\
\hline
\end{tabular}




\section{Interpretation: Chronology of Construction Techniques}

The mean construction date for the poteaux-en-terre structures in this study is 1737, and the mean construction date for the poteaux-sur-solle structures in this study is 1751 (Table 10). Although these statistically-derived dates only vary by 13 years, this indicates a later mean construction date for the poteaux-sur-solle structures than the poteaux-en-terre structures.

Table 10. Statistics Derived from Construction Dates

\begin{tabular}{|c|c|c|}
\hline & Poteaux-en-terre buildings & Poteaux-sur-solle buildings \\
\hline Mean & 1737 & 1751 \\
\hline Median & 1730 & 1760 \\
\hline Mode & 1707 & 1707 \\
\hline Range & 85 years & 85 years \\
\hline
\end{tabular}

The median construction date for the poteaux-en-terre structures in this study is 1730 , and the median construction date for the poteaux-sur-solle structures in this study is 1760 (Table 10). These statistically-derived dates vary by 30 years; this indicates a later median construction date for the poteaux-sur-solle structures than the poteaux-enterre structures.

It is helpful to note that the mean construction date for each group of data represents the average of that group's data set, while the median construction date for each group of data represents the middle point of that group's ranked data set. Therefore, the mean construction date would be less substantially altered than the median 
construction date by the addition to the data set of clusters of similar dates. Thus, the mean construction date reflects the data set taken as a whole, while the median construction date reflects trends in the data set.

The mode construction date for the poteaux-en-terre structures in this study is 1707 , and the mode construction date for the poteaux-sur-solle structures in this study is 1707 (Table 10). Although both statistics are the same, both statistics are a function of the fact that the data set in the poteaux-en-terre category and data set in the poteaux-sursolle category are predominated by the relatively large number (i.e., six in the former, three in the latter) of data points derived from a single geographic region - the Old Mobile (1MB94) structures that were identified archaeologically. Additionally, the data set in the poteaux-en-terre category is skewed by another large number (i.e., five) of data points derived from For Michilimackinac.

The range of construction dates for the poteaux-en-terre structures in this study is 85 (years), and the range of construction dates for the poteaux-sur-solle structures in this study is 85 (years) (Table 10). Although both statistics are the same, a look at the source data reveals that the earliest construction dates in the poteaux-en-terre category and the poteaux-sur-solle category are the same (1707) and are derived from a single region (the Old Mobile structures), and the latest construction dates in the poteaux-en-terre category and the poteaux-sur-solle category are the same (1792) and are derived from a single geographic region (Ste. Genevieve, Missouri).

At first glance, a comparison of a timeline of the construction dates for the poteaux-en-terre structures included in this study and a timeline of the construction dates of the poteaux-sur-solle structures included in this study may appear to indicate a 
relatively even dispersal of both construction types across the entire range of dates between 1702 and 1792. However, upon consideration that the mean and the median construction dates for the poteaux-en-terre structures (1737 and 1730, respectively) predate those for the poteaux-en-terre structures (1751 and 1760, respectively) by 14 years and 30 years, respectively, it becomes evident that the poteaux-en-terre structures, on average, were built 14 years before the poteaux-sur-solle structures; and that the middle period, or height of popularity, for the poteaux-en-terre structures was fully 30 years earlier than that for the poteaux-sur-solle structures.

\section{Interpretation: Geographical Setting}

Of the 21 poteaux-en-terre structures in this study, 12, or 57.14 percent, were situated on a lake/ocean coast (Table 1). Of the 15 poteaux-sur-solle structures in this study, three, or 20.00 percent, were situated on a lake/ocean coast (Table 2).

Six of the 21 poteaux-en-terre structures, or 28.57 percent of the total, were situated at a raised elevation (Table 1). Eight of the 15 poteaux-sur-solle structures, or 53.33 percent; were situated at a raised elevation (Table 2).

Three of the 21 poteaux-en-terre structures, or 14.29 percent, were situated on a river shore/floodplain (Table 1). Four of the 15 poteaux-sur-solle structures, or 26.67 percent, were situated on a river shore/floodplain (Table 2).

These three groups of data-poteaux-en-terre and poteaux-sur-solle structures situated on a lake/ocean coast, situated at a raised elevation, and situated on a river shore/floodplain — are illustrated in Figure 1. 
Figure 1. Geographical Settings of the Poteaux-en-terre and Poteaux-sur-solle Structures

Studied

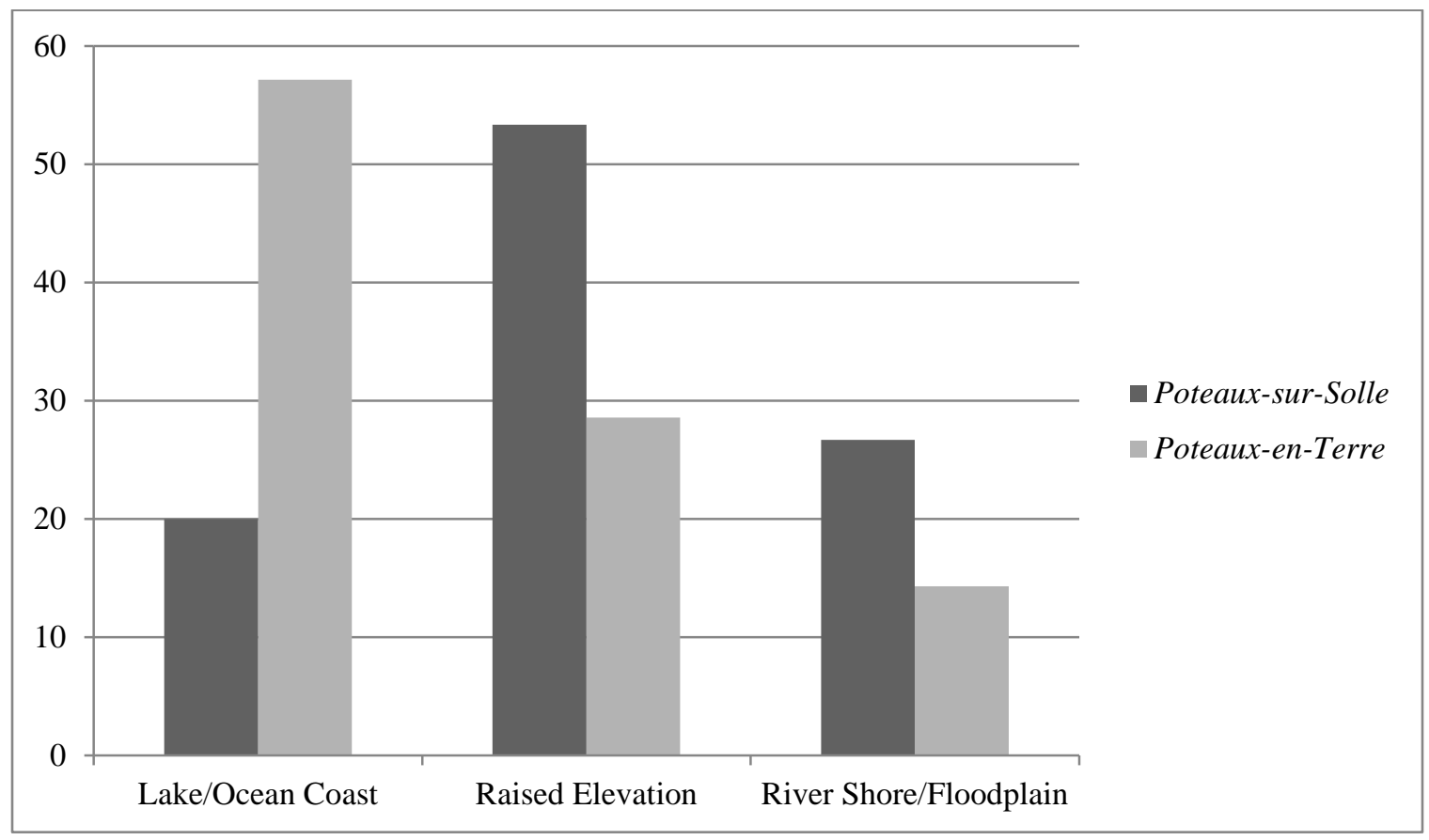

These data indicate that builders most preferred to geographically situate poteauxen-terre structures either on a lake/ocean coast (57.14 percent) or at a raised elevation (28.57 percent); and that the least preferential geographical setting for poteaux-en-terre structures, by far, was on a river shore/floodplain (14.29 percent).

Additionally, these data indicate that builders most preferred to geographically situate poteaux-sur-solle structures at a raised elevation (53.33 percent); and that situating poteaux-sur-solle structures either on a lake/ocean coast (20.00 percent) or on a river shore/floodplain (26.67 percent) were equally likely alternatives, both secondary to raised elevations.

The range of dates of construction for the 12 poteaux-en-terre structures in this study situated on a lake/ocean coast is 1702-1730. The range of dates of construction for 
the three poteaux-sur-solle structures situated on a lake/ocean coast is 1702 . This suggests that, when a building site on a lake/ocean coast was chosen, builders were more likely to build poteaux-en-terre structures than to build poteaux-sur-solle structures. However, it also suggests that, after 1730, French builders in the study area did not choose lake/ocean coast sites for buildings of either vernacular construction type. Although building sites situated on lake/ocean coasts are not so prone to flooding as sites situated in river shores/floodplains, poorly-drained soils in such areas nonetheless would carry a great risk (e.g., via rot, expansion and contraction during freeze/thaw events, etc.) to wooden posts in earth.

The range of dates of construction for the six poteaux-en-terre structures in this study built at a raised elevation is 1733-1792. The range of dates of construction for the eight poteaux-sur-solle structures built at a raised elevation is 1725-1792. These data suggest that between about 1725 and 1792, when building sites at raised elevations were chosen, builders were, roughly speaking, equally as likely to build poteaux-en-terre structures as to build poteaux-sur-solle structures. These data also suggest that builders took great advantage of the characteristics of building sites that were well above the water table, in well-drained soils, and out of the danger of flooding events; such builders used both French vernacular construction techniques. Additionally, noting that the range for both types of construction technique, in this geographical setting, is greater than the range for either type in either of the other geographical settings, it can be stated that using vernacular construction techniques at raised elevations appears to have been more popular than using them in other geographical settings. 
The range of dates of construction for the three poteaux-en-terre structures in this study situated on a river shore/floodplain is $1740-1766$. The range of dates of construction for the four poteaux-sur-solle structures situated on a river shore/floodplain is 1760-1790. These data indicate that, although sites within a river shore/floodplain context were being chosen for constructing traditional buildings from 1740 until 1790, builders used the poteaux-en-terre method before and until the mid-1760s, after which time builders used only the poteaux-sur-solle method. Such a transition is not unexpected; the river shore/floodplain setting is most susceptible to perennial seasonal flooding, and building in the poorly-drained soils in such areas would carry the risks of exposing wood posts in earth to natural process such as rot, and expansion and contraction during freeze/thaw events.

In regard to the chronological patterning of poteaux-en-terre structures studied, the overall chronological shifts seem clear; structures were built from 1707 to 1730 situated on lake/ocean coasts, from 1733 to 1735 situated at raised elevations, from 1740 to 1766 situated on river shores/floodplains, and from 1779 to 1792 situated at raised elevations. However, in regard to the chronological patterning of poteaux-sur-solle structures studied, the overall chronological shifts seem less clear; structures were built around 1707 situated on lake/ocean coasts, from 1725 to 1740 situated at raised elevations, and from 1760 to 1792 situated both at raised elevations and on river shores/floodplains.

\section{Interpretation: Chronology of Settlement Locations}

A rough chronology of the construction of buildings in North America using traditional French construction methods at specific settlement locations and in specific 
geographical settings can be derived from the data. Initially, such structures were being built Old Mobile (1MB94), Mobile County, Alabama, situated on a lake/ocean coast (mean 1707; median 1707); at Fort Michilimackinac, situated on a lake/ocean coast (mean 1728; median 1730); and at Cahokia, Illinois, situated on a raised elevation (mean 1731; median 1730). It is unsurprising that these settlements were earliest - and that they left behind considerable documentary records and archaeological resources. After all, each was heavily comprised of institutional (i.e., military and religious) personnel, and thus, each had broader funding resources than most individuals or families would have had. Furthermore, such institutionally-supported settlements would have had the ability, via connections to the Crown and the Church, to choose the best geographical settings (i.e., not in, or nearby to, a floodplain); and would have had greater labor resources upon which to draw.

Next, traditional French construction methods were being used to build structures at Cahokia, Illinois, situated on a river shore/floodplain (mean 1754; median 1760); at Natchitoches Parish, situated on a raised elevation, (mean 1758; median 1770); at Ste. Genevieve, Missouri, situated on a river shore/floodplain (mean 1766; median 1766); at New Orleans, Louisiana, situated on a river shore/floodplain (mean 1780; median 1780); at Ste. Genevieve, Missouri, situated on a raised elevation (mean 1785, median 1791); and at Prairie du Pont, Illinois, situated on a river shore/floodplain (mean 1790; median 1790). Most of these structures were built by individuals or families. Again, it seems unsurprising that these settlements - comprised, as they were, mostly of individuals and families - would have come on the heels of the institutional settlements. The institutional settlements would have been established for several decades, by the time these secondary 
settlements were founded; the former would have laid the groundwork for the latter in these areas, in terms of civil and religious law, social and economic systems, and relations with Native American groups.

\section{Summary}

In summary, the data presented in this study indicate that the middle period, or height of popularity, for the poteaux-en-terre structures was fully 30 years earlier than that for the poteaux-sur-solle structures. Additionally, the data indicate that, when a building site on a lake/ocean coast was chosen, builders were more likely to build poteaux-en-terre structures than to build poteaux-sur-solle structures; and that, after 1730, French builders in the study area did not choose lake/ocean coast sites for buildings of either vernacular construction type. Furthermore, the data suggest that between about 1725 and 1792, when building sites at raised elevations were chosen, builders were as likely to build poteaux-en-terre structures as to build poteaux-sur-solle structures, and that builders utilized building sites that were well above the water table, in well-drained soils, and out of the danger of flooding events. Moreover, the data indicate that, although sites within a river shore/floodplain context were being chosen for constructing traditional buildings from 1740 until 1790, builders used the poteaux-en-terre method before and until the mid-1760s, after which time builders used only the poteaux-sur-solle method.

Finally, a rough chronology of the construction of buildings in North America using traditional French construction methods at specific settlement locations and in specific geographical settings has been derived, indicating that, initially, such structures were being built at settlements heavily comprised of institutional (i.e., military and 
religious) personnel; typically, it would be decades before substantial settlements peopled by individuals and families would be established — after the institutional settlements would have laid the groundwork in these areas, in terms of civil and religious law, social and economic systems, and relations with Native American groups. 


\section{CHAPTER V}

\section{CONCLUSIONS AND RECOMMENDATIONS}

My study examined published and unpublished historical archaeological research, historical documents research, and datable extant buildings to develop a temporal and geographical sequence of French colonial architectural designs and construction methods, particularly the poteaux-en-terre (posts-in-ground) and poteaux-sur-solle (posts-on-sill) elements in vernacular buildings, from the Western Great Lakes region to Louisiana, dating from 1702 to 1792 .

The analysis of statistically-derived data produced a number of interpretations. For instance, a later mean construction date was indicated for the poteaux-sur-solle structures than for the poteaux-en-terre structures. Additionally, a later median construction date was indicated for the poteaux-sur-solle structures than for the poteauxen-terre structures. Futhermore, the mode construction dates for the poteaux-en-terre structures and for the poteaux-sur-solle structures were the same. (This had much to do with the fact that data sets both for the poteaux-en-terre category and for the poteaux-sursolle category were predominated by a relatively large number, in each, of data points derived from a single geographic region.) Finally, both the range of construction dates for the poteaux-en-terre structures, and the range of construction dates for the poteauxsur-solle structures, are 85 (years). (This had much to do with that fact that the earliest construction dates in the poteaux-en-terre category and the poteaux-sur-solle category are the same [1707] and are derived from a single region [the Old Mobile structures], and the 
latest construction dates in the poteaux-en-terre category and the poteaux-sur-solle category are the same [1792] and are derived from a single geographic region [Ste. Genevieve, Missouri].

Although initially, a comparison of a timeline of the construction dates for the poteaux-en-terre structures included in this study and a timeline of the construction dates of the poteaux-sur-solle structures included in this study may appear to indicate a relatively even dispersal of both construction types across the entire range of dates between 1702 and 1792; upon consideration that the mean and the median construction dates for the poteaux-en-terre structures (1737 and 1730, respectively) predate those for the poteaux-en-terre structures (1751 and 1760, respectively) by 14 years and 30 years, respectively, it becomes evident that the poteaux-en-terre structures, on average, were built 14 years before the poteaux-sur-solle structures; and that the middle period, or height of popularity, for the poteaux-en-terre structures was fully 30 years earlier than that for the poteaux-sur-solle structures.

The analysis of geographical setting, likewise, provided a number of interpretations. For instance, French builders in North America most preferred to geographically situate both poteaux-en-terre and poteaux-sur-solle structures at raised elevations; less preferential was geographically situating either type of structure on a floodplain; and least preferential was geographically situating either type of structure on a coastline. Additionally, when building sites at raised elevations were chosen, both poteaux-en-terre and poteaux-sur-solle styles were popular between 1702 and 1792; however, builders using such sites were more likely to build poteaux-en-terre structures than to build poteaux-sur-solle structures. Furthermore, between 1740 and 1790, when 
building sites on floodplains were chosen, builders were more likely to build poteauxsur-solle structures than to build poteaux-en-terre structures. However, because this assertion is based upon the fact that the construction dates of only one of each type of structure (i.e., the Nicolle/Meunier House [1759-1765], a poteaux-en-terre structure; and the Langedoc House [1760, a poteaux-sur-solle structure]) overlap, it seems more reasonable to suggest that, for buildings sites on floodplains, the poteaux-en-terre structure style yielded to the poteaux-sur-solle structure style during 1760-1765. Finally, after 1715, buildings sites on coastlines simply were not chosen-either for poteaux-enterre structures or for poteaux-sur-solle structures.

Finally, a rough chronology of the construction of buildings in North America using traditional French construction methods at specific settlement locations and in specific geographical settings has been derived, indicating that such structures first were being built at settlements heavily comprised of institutional (i.e., military and religious) personnel; in most areas several decades would pass, before substantial settlements peopled by individuals and families would be established.

\section{Conclusions}

As early as 1702, French colonists at Old Mobile were using both traditional poteaux-en-terre and traditional poteaux-sur-solle methods for new building construction projects. As late as 1792, French colonists in Ste. Genevieve, Missouri, were using both traditional poteaux-en-terre and traditional poteaux-sur-solle methods for new building construction projects.

French colonists' usage, during this same North America colonial period, of piece-sur-piece (piece-on-piece) construction methods (Gums 2002:14-15; Peterson 
2001:46), as well as the usage of stone for foundation walls, indicate progressive adaptations to geographical setting, exploitation of local materials, and incorporation of construction technologies of other groups, and even could be interpreted as indicators of cultural change, creolization, and ethnogenesis. However, the persistence of the usage, during the same period, of both poteaux-en-terre and poteaux-sur-solle methods of building construction — both vernacular building methods that they had brought with them from their homeland to places along the Mississippi River Valley such as Ste. Genevieve and Cahokia—indicates that French colonists probably placed value upon maintaining these very visible elements of their cultural traditions.

As discussed in Chapter I, in order to establish both a temporal and geographical sequence, this research was to be used to address how information from archaeological reports and extant dated buildings can be used to answer certain research questions, which will be repeated, and then addressed, after each.

Question 1) Can measurable temporal and geographical sequences be derived in vernacular architecture, from present historical archaeological data and extant dated buildings?

Measurable temporal and geographical sequences in French vernacular architecture can be, and were in this study, derived from present historical archaeological data and extant dated buildings. However, it is important to note that any preponderance of data derived from well-documented historical sources or well-investigated archaeological resources can serve to skew statistics, and thereby may skew the interpretations. The measurable sequences derived in this study indicated both a persistence by the French to use traditional building methods and a willingness and 
ability to adapt those methods for use in new geographical areas and situations, and to adapt to new contexts (e.g., institutional building, slave labor, etc.).

Question 2) Did French colonists either replace poteaux-en-terre (posts-inground) with poteaux-sur-solle (posts-on-sill), or vice versa, or did they build in both styles contemporaneously; and if so, can measurable temporal and geographical sequences be derived to demonstrate such patterns?

In this study, measurable temporal and geographical sequences were derived to demonstrate patterns. For example, French colonists built in both styles contemporaneously throughout the $18^{\text {th }}$ century, from about 1702 to about 1792 . However, by the mid-1760s, the poteaux-sur-solle construction method had supplanted the poteaux-en-terre construction method for structures situated on a river shore/floodplain.

Question 3) How might such sequences, if found, be used to tie research of French vernacular architectural design and construction methods in North America into the larger body of scholarship in French colonialism?

Such sequences might be used to serve as springboards for broader studies of French colonial culture in North America and elsewhere, or as bases for seriation studies (for example) which in turn might seek to interpret the functional relationship of vernacular architecture to colonial culture.

Question 4) What would retention of traditional French architectural designs and construction methods indicate?

Retention of traditional French architectural designs and methods indicates a desire to utilize existing, culturally-formed, and culturally accepted construction ways, in 
order to display and promote Frenchness within one's group, as well as to other groups (e.g., British, other Europeans, Native Americans, etc.). Both within and without one's group, such methods would serve to bolster one's social position and cultural identity.

Question 5) What would be indicated by the adaptation of architectural designs and methods of indigenous peoples or slaves in French Colonial architecture?

The adaption of architectural design and methods of indigenous peoples or slaves in French Colonial architecture indicates that the French colonists, while desirous of maintaining elements of their culture in the New World, nonetheless understood the benefits of learning from the natives (e.g., how to prepare their buildings for local climates) and maximizing the efficiencies of their slaves (e.g., in terms of designing structures that would be familiar to the slaves, in order that the structures might be constructed in a minimum amount of time, and with a minimum amount of effort). While perhaps not foremost in the minds of the French colonizers at the time of the construction of such buildings that used non-traditional French elements, such adaptations nonetheless serve to indicate cultural change, and indicate that processes of creolization were occurring. Additionally, the process of ethnogenesis - in this case, the creation of a French colonial culture in the New World-was under way; the mere fact that these Europeans had transplanted themselves into an unfamiliar land did not mean that such aspects of culture as social position and lifeways had no meaning or place. If anything, culture would have played a more important role, in terms of establishing and maintaining the cohesion required for the culture to survive.

However, other factors besides cultural tradition could explain the co-occurrence of poteaux-en-terre and poteaux-sur-solle methods of building construction. One 
variable that would have had great effect upon the quality of building site and type of construction method chosen is economic position. Whereas persons or families of few means likely would have had to settle for less-than-desirable building sites (e.g., on coastlines or floodplains) and less-than-desirable materials (e.g., wood species exhibiting low or moderate resistance to insect infestation, mold, and rot), wealthy individuals would have been able to afford to purchase desirable building sites (e.g., on raised elevations) and desirable materials (e.g., wood species exhibiting high resistance to insect infestation, mold, and rot; or stone). Additionally, individuals and families of high economic position would have been more likely than individuals and families of low economic position to able to draw upon human resources such as paid contractors, employees, and slaves for the construction of buildings.

Similarly, building construction efforts associated with governmental or religious institutions, such as military expeditions or religious missions, likely would have had access to greater sources of funds and manpower than those efforts associated with individuals and families. Again, these greater resources from which to draw would have translated into an enhanced ability to identify and acquire building materials of superior quality (i.e., wood species exhibiting the highest resistance to insect infestation, mold, and rot; or even stone) to build, maintain, repair, and replace structures more readily and more quickly.

Other variables that would have had certain effects upon the choice between using poteaux-en-terre or poteaux-sur-solle methods of building construction would have been the relationship of a building site to a nearby watercourse or drainage basin (e.g., on a coastline, in a floodplain, or on a raised elevation); a site's soil preservation conditions 
(e.g., poorly-drained soils, or well-drained soils); and the availability and proximity of appropriate, adequate materials (e.g., wood species exhibiting the highest resistance to insect infestation, mold, and rot; or even stone). Additionally, economic position ties into this variable, as well. For example, if soil conditions are such that a poteaux-en-terre structure would suffer from rot, then an individual of higher economic position would be able to afford stone for a poteaux-sur-solle structure, which would both be longer-lasting and more expensive to construct, than would a person of lower economic position.

\section{Recommendations}

In regard to further recommendations, future studies might productively study such things as relationships between vernacular buildings designed and/or constructed by specific individuals (e.g., owners or builders) or specific groups (e.g., missionary institutions or military units); comparisons of buildings within specific French colonial settlements over time; comparisons of buildings constructed for landowners and householders, and buildings constructed for slaves; differences of vernacular construction techniques used in residential structures, outbuildings, and commercial structures; temporal alterations of vernacular structures; historical use of construction materials (e.g., wood, stone, etc.) and wood species and stone type. While it might be useful for future scholars to include such factors as climate zone, Köppen Climate classification, Holdridge Life Zone classification, hardiness zone, Biome, soil type(s), and soil pH, such studies as might include these factors likely would require considerably more time and resources (e.g., access to soil maps, historical atlas research, historical climate research to ascertain climatic changes over time or over specific geographic areas, USGS quadrangle 
maps for each area, and research into both natural changes and cultural alterations to watercourses, watersheds, and grades/terrains).

Additionally, future studies might productively study how French colonists' choices of designs and methods were affected by economic realities, environments (e.g., local water tables, proximities to navigable waterways, and propensities toward flooding), climate (e.g., historical freeze/thaw cycles, and historical wet/dry cycles), available raw materials (e.g., species of trees, elements of typical bousillage compositions, and varieties of building stones), and soils (e.g., types, compositions, water retention and drainage characteristics, and acidities).

Any study of this type benefits from a discussion of how it might have been affected by sample size. In the case of this study, a single source-Old Mobile (1MB94) accounted for nearly half of the included structures; of these, about 80 percent were poteaux-en-terre. Do poteaux-en-terre structures tend to be preserved better in the ground than in the documentation? Because the archaeologically-derived data included in this study tend significantly toward poteaux-en-terre rather than poteaux-sur-solle, it can be speculated that if a larger archaeologically-derived data sample were included, this trend would continue.

This initial study has indicated that French colonists probably placed great value upon maintaining the very visible elements of their cultural traditions through their buildings. Using traditional designs and construction methods were methods of maintaining social and economic relationships with each other, displaying social cohesion towards others, and maintaining power relationships with others. The potential is great for future research into how French vernacular architectural designs and 
construction techniques in North America were affected by the particular individuals or groups who undertook the work, as well as how designs and techniques were affected by climate and access to materials. 


\section{REFERENCES}

Balesi, Charles J.

2000 The Time of the French in the Heart of North America, 1673-1818. Alliance

Francaise Chicago, Chicago, Illinois.

Beavers, Richard C.

1983 Preliminary Archaeological Reconnaissance and Assessment of Acadia

Plantation, LaFourche Parish, Louisiana. University of New Orleans Department of Anthropology and Geography Archaeological and Cultural Research Program

Research Report No. 6. University of New Orleans, New Orleans, Louisiana.

Belting, Natalia M.

2003 [1948] Kaskaskia Under the French Regime. Southern Illinois University Press, Carbondale, Illinois.

Birk, Douglas A.

1991 French Presence in Minnesota: The View from Site Mo20 near Little Falls. In French Colonial Archaeology: The Illinois Country and the Western Great Lakes, edited by John A. Walthall, pp. 237-266. University of Illinois Press, Urbana.

Boyer, Marcel

2001 Plantations by the River: Watercolor Paintings from St. Charles Parish, Louisiana, 1859, by Father Joseph M. Paret. The Fred B. Kniffen Cultural Resources Laboratory Monograph Series No. 4. Louisiana State University Press, Baton Rouge, Louisiana.

Chamberlain, Samuel

1981 [1928] Domestic Architecture in France. Architectural Book Publishing Company, Inc., New York, New York.

Dawdy, Shannon Lee

2000 Understanding Cultural Change Through the Vernacular: Creolization in Louisiana. Historical Archaeology 34(3):107-123.

Digital Archaeological Record, The 2004a Old Mobile (1MB94) Structure 01, Mobile County, Alabama; The Digital Archaeological Record: A Service of Digital Antiquity; Arizona State University, Phoenix. <http://core.tdar.org/project/380900> Accessed July 15, 2014. 
Digital Archaeological Record, The 2004b Old Mobile (1MB94) Structure 02, Mobile County, Alabama; The Digital Archaeological Record: A Service of Digital Antiquity; Arizona State University, Phoenix. <http://core.tdar.org/project/380901> Accessed May 24, 2013.

Digital Archaeological Record, The 2004c Old Mobile (1MB94) Structure 03, Mobile County, Alabama; The Digital Archaeological Record: A Service of Digital Antiquity; Arizona State University, Phoenix. <http://core.tdar.org/project/380924> Accessed July 1, 2014.

Digital Archaeological Record, The 2004d Old Mobile (1MB94) Structure 04, Mobile County, Alabama; The Digital Archaeological Record: A Service of Digital Antiquity; Arizona State University, Phoenix. <http://core.tdar.org/project/380947> Accessed May 22, 2013.

Digital Archaeological Record, The 2004e Old Mobile (1MB94) Structure 05, Mobile County, Alabama; The Digital Archaeological Record: A Service of Digital Antiquity; Arizona State University, Phoenix. <http://core.tdar.org/project/380949> Accessed February 1, 2014.

Digital Archaeological Record, The 2004f Old Mobile (1MB94) Structure 14, Mobile County, Alabama; The Digital Archaeological Record: A Service of Digital Antiquity; Arizona State University, Phoenix. <http://core.tdar.org/project/380950> Accessed May 19, 2013.

Digital Archaeological Record, The 2004g Old Mobile (1MB94) Structure 30, Mobile County, Alabama; The Digital Archaeological Record: A Service of Digital Antiquity; Arizona State University, Phoenix. <http://core.tdar.org/project/380902> Accessed August 14, 2014.

Edwards, Jay

2006 Creole Architecture: A Comparative Analysis of Upper and Lower Louisiana and Saint Domingue. International Journal of Historical Archaeology 10(3):241-271.

Edwards, Jay D., and Nicolas Kariouk Pecquet du Bellay de Verton 2004 A Creole Lexicon: Architecture, Landscape, People. Louisiana State University Press, Baton Rouge, Louisiana.

Ekberg, Carl J. 1996 Colonial Ste. Genevieve: An Adventure on the Mississippi Frontier. The Patrice Press, Tucson, Arizona. 2000 French Roots in the Illinois Country: The Mississippi Frontier in Colonial Times. University of Illinois Press, Urbana, Illinois. 2002 Louis Bolduc: His Family and His House. The Patrice Press, Tucson, Arizona. 
Evans, Lynn L. M.

2001 House D of the Southeast Row House: Excavations at Fort Michilimackinac, 1989-1997. Archaeological Completion Report Series, Number 17. Mackinac State Historic Parks, Mackinac Island, Michigan.

Evans, Mark L.

2001 The Commandant's Last Ride. Ten-digit Press, Cape Girardeau, Missouri.

Faulkner, Alaric

1992 Gentility on the Frontiers of Acadia, 1635-1674: An Archaeological Perspective. In New England/New France, 1600-1850, edited by Peter Benes, pp. 82-100. Boston University Press, Boston.

Faulkner, Alaric, and Gretchen Faulkner

1987 The French at Pentagoet: An Archaeological Portrait of the Acadian Frontier. Maine Historic Preservation Commission and New Brunswick Museum, Augusta, Maine.

Franzwa, Gregory M.

1998 The Story of Old Ste. Genevieve. 6th ed. The Patrice Press, Tucson, Arizona.

Gérin-Lajoie, Marie

1976 Fort Michilimackinac in 1749: Lotbinière's Plan and Description. Mackinac

History Vol. 2, Leaflet No. 5. Mackinac Island State Park Commission, Mackinac Island, Michigan.

Gitlin, Jay

1992 On the Boundaries of Empire: Connecting the West to Its Imperial Past. In Under an Open Sky: Rethinking American's Western Past, edited by W. Cronon, G. Miles, and J. Gitlin, pp. 71-89. W. W. Norton, New York.

Gould, Philip, Richard Seale, Robert DeBlieux, and Harlan Mark Guidry. 2002 Natchitoches and Louisiana's Timeless Cane River. Louisiana State University Press, Baton Rouge, Louisiana.

Gregory, H. G., George A. Stokes, with Shelia Morrison, Melissa Green, and Abigayle Robbins

1982 The Archaeology of the Badin-Roque House: A $19^{\text {th }}$ Century Poteau-en-Terre

House, Natchitoches Parish, Louisiana. Division of Archaeology No. 820.

St. Augustine Historical Society, Melrose, Louisiana.

Groover, Mark D.

1994 Evidence for Folkways and Cultural Exchange in the 18th-Century South Carolina Backcountry. Historical Archaeology Vol. 28(1):41-64. 
Gums, Bonnie L.

1988 Archaeology at French Colonial Cahokia. Studies in Illinois Archaeology No. 3.

Illinois Historic Preservation Agency, Springfield, Illinois.

2002 Earthfast (Pieux en Terre) Structures at Old Mobile. In "French Colonial

Archaeology at Old Mobile: Selected Studies." Historical Archaeology 36(1): 13-25.

2004 Old Mobile (1MB94) Structure 32, Mobile County, Alabama; The Digital

Archaeological Record: A Service of Digital Antiquity; Arizona State University, Phoenix. <http://core.tdar.org/project/380897> Accessed July 15, 2014.

Gums, Bonnie L., William R. Iseminger, Molly E. McKenzie, and Dennis D. Nichols 1991 The French Colonial Villages of Cahokia and Prairie du Pont, Illinois. In French Colonial Archaeology: The Illinois Country and the Western Great Lakes, edited by John A. Walthall, pp. 85-122. University of Illinois Press, Urbana.

Gums, Bonnie L., and George W. Shorter, Jr. 2004 Old Mobile (1MB94) Structure 31, Mobile County, Alabama; The Digital Archaeological Record: A Service of Digital Antiquity; Arizona State University, Phoenix. <http://core.tdar.org/project/380898> Accessed August 14, 2014.

Halchin, Jill Y.

1985 Excavations at Fort Michilimackinac, 1983-1985: House C of the Southeast Row

House (The Solomon-Levy-Parant House). Archaeological Completion Report Series No. 11. Mackinac Island State Park Commission, Mackinac Island, Michigan.

Hall, Robert L.

1991 The Archaeology of La Salle's Fort St. Louis on Starved Rock and the Problem of the Newell Fort. In French Colonial Archaeology: The Illinois Country and the Western Great Lakes, edited by Walthall, John A., pp.14-28. University of Illinois Press, Urbana, Illinois.

Heldman, Donald P.

1977 Excavations at Fort Michilimackinac, 1976: The Southeast and South Southeast

Row Houses. Archaeological Completion Report Series, Number 1. Mackinac Island State Park Commission, Mackinac Island, Michigan.

1978 Excavations at Fort Michilimackinac, 1977: House One of the South Southeast

Row House. Archaeological Completion Report Series, Number 2. Mackinac Island State Park Commission, Mackinac Island, Michigan.

Heldman, Donald P., and Roger T. Grange, Jr.

1981 Excavations at Fort Michilimackinac: 1978-1979: The Rue de la Babillarde. Archaeological Completion Report Series, Number 3. Mackinac Island State Park Commission, Mackinac Island, Michigan. 
Heldman, Donald P., and William L. Minnerly

1977 The Powder Magazine at Fort Michimackinac: Excavation Report. Reports in Mackinac History and Archaeology, Number 6. Mackinac Island State Park Commission, Mackinac Island, Michigan.

National Parks Service

1985 Historic American Buildings Survey. United States Department of the Interior, Washington, D. C.

Jelks, Edward B., Carl J. Ekberg, and Terrance J. Martin 1989 Excavations at the Laurens Site: Probable Location of Fort de Chartres I. Studies in Illinois Archaeology No. 5. Illinois Historic Preservation Agency, Springfield, Illinois.

Katz, Ron

2004 French America: French Architecture from Colonialization to the Birth of a Nation. French Heritage Society, New York, New York.

Keene, David

1991 Fort de Chartres: Archaeology in the Illinois Country. In French Colonial Archaeology: The Illinois Country and the Western Great Lakes, edited by Walthall, John A., pp. 29-41. University of Illinois Press, Urbana, Illinois.

Kingsley, Karen

2003 Buildings of Louisiana. Society of Architectural Historians Buildings of the United States. Oxford University Press, Inc. New York, New York.

Koeper, Frederick

1968 Illinois Architecture: From Territorial Times to the Present, A Selective Guide. The University of Chicago Press, Chicago, Illinois.

Lamb, Teresia R.

1983 Preliminary Archaeological Reconnaissance and Assessment of Destrehan Plantation, St. Charles Parish, Louisiana. University of New Orleans Department of Anthropology and Geography Archaeological and Cultural Research Program Research Report No. 5. University of New Orleans, New Orleans, Louisiana.

Leone, Mark P.

1988 The Georgian Order as the Order of Merchant Capitalism in Annapolis, Maryland. In The Recovery of Meaning: Historical Archaeology in the Eastern United States, pp. 235-261. Smithsonian Institution Press, Washington, D.C. 
Louisiana Regional Folklife Program

n.d. Badin-Roque House (also known as the Sylvie-Badin House), Louisiana Regional Folklife Program, Northwestern State University of Louisiana, Natchitoches. <http://winhttp.nsula.edu/regionalfolklife/crcc/badinroque.html>. Accessed September 14, 2014.

Mann, Rob

2008 From Ethnogenesis to Ethnic Segmentation in the Wabash Valley: Constructing Identity and Houses in Great Lakes Fur Trade Society. International Journal of Historical Archaeology 12:319-337.

Markell, Ann, R. Christopher Godwin, Susan B. Smith, and Ralph Draughon 1999 Patterns of Change in Plantation Life in Pointe Coupee Parish, Louisiana: The Americanization of Nina Plantation, 1820-1890. R. Christopher Goodwin \& Associates, Inc. Prepared for U. S. Army Corps of Engineers, Contract No. DACW29-93-C-0089. Copies available from R. Christopher Goodwin \& Associates, Inc., New Orleans, Louisiana.

Maygarden, Benjamin D.

2006 Building in Colonial Louisiana: Creolization and the Survival of French Traditions. International Journal of Historical Archaeology 10 (3):211-239.

Mazrim, Robert F.

n.d. Colonial Cahokia: The Duckhouse Site/The Gammon Site/The Jarrot Mansion, Sangamo Archaeological Center, Sangamo Archaeological Center, Springfield. <http://www.sangamoarchaeology.org/ColonialCahokia.html〉. Accessed August $28,2014$.

McAlester, Virginia, and Lee McAlester 1990 A Field Guide to American Houses. Alfred A. Knopf, New York.

Mueller, James W., and Judith A. Newkirk 1981 A Cultural Resources Survey of the Red River Valley Waterway from Shreveport, Louisiana to the Mississippi River. Commonwealth Associates Inc. Submitted to the U. S. Army Engineer District, New Orleans.

Muller, J.

1986 Archaeology of the Lower Ohio River Valley. Academic Press. Orlando.

Nassaney, Michael S

2008 Identity Formation at a French Colonial Outpost in the North American Interior. International Journal of Historical Archaeology 12(4):297-319.

Nassaney, Michael S., Jose A. Brandao, William M. Cremin, and Brock A. Giordano 2007 Archaeological Evidence of Economic Activities at an Eighteenth-Century Frontier Outpost in the Western Great Lakes. Historical Archaeology 41(4):3-19. 
Nassaney, Michael S., William M. Cremin, Daniel P. Lynch

2002 The Identification of Colonial Fort St. Joseph, Michigan. Journal of Field Archaeology 29 (3/4): 309-321.

Peterson, Charles E.

1938 French Houses of the Illinois Country. Missouriana 1(4):9-12.

1999 Notes on Old Cahokia. Jarrot Mansion Project, Inc., Cahokia, Illinois.

2001 Colonial St. Louis: Building a Creole Capital. The Patrice Press, Tucson, Arizona.

Richey, Sheila

2007 Fort Massac History. Southernmost Illinois History.

<http://www.southernmostillinoishistory.net/fort-massac.html>. Accessed September $14,2014$.

Robb, John

2007 The Early Mediterranean Village: Agency, Material Culture, and Social Change in Neolithic Italy. Cambridge University Press, New York.

Sambrook, Richard A.

1992 Thematic Innovation on the North American Colonial Frontier: Comparisons of the Four Historic Maps of Fort Michilimackinac, Michigan, 1749-1769. The Geographical Bulletin 34 (1).

Saucier, Walter J., and KathrineWagner Seineke 1969 François Saucier, Engineer of Fort de Chartes, Illinois. In Frenchmen and French Ways in the Mississippi Valley, edited by John Francis McDermott, pp. 199229. University of Illinois Press, Urbana, Illinois.

Seale, Richard, Robert DeBlieux, and Harlan Mark Guidry 2002 Natchitoches and Louisiana's Timeless Cane River. Louisiana State University Press, Baton Rouge, Louisiana.

South, Stanley

1979 Historic Site Content, Structure, and Function. American Antiquity (44)2):213237.

Skowronek, Russell K. 1998 The Spanish Philippines: Archaeological Perspectives on Colonial Economics and Society. International Journal of Historical Archaeology (2)1. 
Steen, Carl

2002 John de la Howe and the Second Wave of French Refugees in the South Carolina Colony: Defining, Maintaining, and Losing Ethnicity on the Passing Frontier. In Another's Country: Archaeological and Historical Perspectives on Cultural Interactions in the Southern Colonies, edited by J. W. Joseph, and Martha Zierden, pp. 145-160. University of Alabama Press, Birmingham.

Stepenoff, Bonnie

2006 From French Community to Missouri Town: Ste. Genevieve in the Nineteenth Century. University of Missouri Press, Columbia, Missouri.

Stone, Lyle M.

1972 Archaeological Investigation of the Marquette Mission Site, St. Ignace, Michigan, 1971: A Preliminary Report. Reports in Mackinac History and Archaeology, Number 1. Mackinac Island State Park Commission, Mackinac Island, Michigan.

Thurman, Melburn D.

1984 Building a House in 18th Century Ste. Genevieve. Pendragon's Press, Ste. Genevieve, Missouri.

Toledano, Roulhac, and Mary Louise Christovich 1980 New Orleans Architecture, Volume VI: Faubourg Tremé and the Bayou Road. Pelican Publishing Company, Gretna, Louisiana.

Usner, Daniel H., Jr.

1987 The Frontier Exchange Economy of the Lower Mississippi Valley in the Eighteenth Century. The William and Mary Quarterly 44(2):165-192.

Vauban, Sebastien LePrestre de 1968 [1737 and 1740] A Manual of Siegecraft and Fortification. The University of Michigan Press, Ann Arbor, Michigan.

Walker, John W.

1971 Excavation of the Arkansas Post Branch of the Bank of the State of Arkansas, Arkansas Post National Memorial, Arkansas. Southeast Archeological Center, Division of Archaeology, Office of Archeology and Historic Preservation. National Park Service, U. S. Department of the Interior.

Walthall, John A. 1991 French Colonial Fort Massac: Architecture and Ceramic Patterning. In French Colonial Archaeology: The Illinois Country and the Western Great Lakes, edited by John A.Walthall, pp. 42-64. University of Illinois Press, Urbana, Illinois. 
Walthall, John A., and Thomas E. Emerson 1991 French Colonial Archaeology. In French Colonial Archaeology: The Illinois Country and the Western Great Lakes, edited by John A. Walthall, pp. 1-13. University of Illinois Press, Urbana, Illinois.

Walthall, John A., and Elizabeth D. Benchley 1987 The River L'Abbe Mission: A French Colonial Church for the Cahokia Illini on Monks Mound. Studies in Illinois Archaeology No. 2. Illinois Historic Preservation Agency, Springfield, Illinois.

Waselkov, Gregory A. (editor) 1997 French Colonial Archaeology at Old Mobile. Special Publication (36)1. The Society for Historical Archaeology.

Waselkov, Gregory A. 2001 The Archaeology of French Colonial North America English-French Edition. Guides to Historical Archaeological Literature No. 5. The Society for Historical Archaeology.

2005 Old Mobile Archaeology. University of Alabama Press.

Waselkov, Gregory A., and Bonnie L. Gums 2000 Plantation Archaeology at Rivière aux Chiens, ca. 1725-1848. University of South Alabama Archaeological Monograph No. 7. University of South Alabama Center for Archaeological Studies, Mobile, Alabama.

Wolf, Eric R.

1997 [1982] Europe and the People without History. University of California Press, Berkeley, California.

Yakubik, Jill-Karen, and Rosalinda Méndez 1992 Beyond the Great House: Archaeology at Ashland-Belle Helene Plantation. Discovering Louisiana Archaeology No. 1. Louisiana Department of Culture, Recreation and Tourism Division of Archaeology, Baton Rouge, Louisiana. 